\title{
New species of deep-sea Antipatharians from the North Pacific (Cnidaria: Anthozoa: Antipatharia), Part 2
}

\author{
DENNIS M. OPRESKO ${ }^{*} \&$ TINA N. MOLODTSOVA ${ }^{2}$ \\ ${ }^{1}$ Department of Invertebrate Zoology, National Museum of Natural History, Smithsonian Institution, Washington, DC 20560, USA. \\ "'dmopresko@hotmail.com; @ ittps://orcid.org/0000-0001-9946-1533 \\ ${ }^{2}$ P.P. Shirshov Institute of Oceanology, RAS, 36 Nakhimovsky prospect, Moscow 117997, Russia \\ ఏ"tina@ocean.ru; @ https://orcid.org/0000-0001-7171-6952 \\ ${ }^{*}$ Corresponding author
}

\begin{abstract}
Five new species of deep-sea antipatharian corals are described from the North Pacific primarily collected off the coast of Alaska and on adjacent seamounts. All the species are referred to the family Schizopathidae. Described as new are: Alternatipathes mirabilis, Bathypathes ptiloides, Bathypathes tiburonae, Bathypathes alaskensis, and Parantipathes pluma. Illustrations of the type material of Bathypathes patula, B. patula var. plenispina and B. tenuis are provided for comparative proposes. Bathypathes patula var. plenispina is here recognized as a species distinct from B. patula, and $B$. tenuis is considered incertae sedis due to the poor condition of the type material.
\end{abstract}

Key words: Cnidaria, Anthozoa, Antipatharia, Schizopathidae, new species, North Pacific

\section{Introduction}

This is the second in a series of papers dealing with the deep-sea antipatharian fauna of the North Pacific, and primarily with species found off the coast of Alaska and on adjacent seamounts. In the first report, nine new species were described, including: Bathypathes seculata Opresko, 2005, Umbellapathes helioanthes Opresko, 2005, U. bipinnata Opresko, 2005, Dendrobathypathes boutillieri Opresko, 2005, D. fragilis Opresko, 2005, Dendropathes bacotaylorae Opresko, 2005, Lillipathes wingi Opresko, 2005, Chrysopathes gracilis Opresko, 2005, and Heliopathes pacifica Opresko, 2005. Umbellapathes bipinnata has since been placed in a separate genus Alternatipathes Molodtsova \& Opresko, 2017, Bathypathes seculata has been found to be a synonym of Bathypathes patula Brook, 1889 (Horowitz et al. 2018), and Heliopathes pacifica is now placed in the genus Heteropathes Opresko, 2011, due to the fact that Heliopathes Opresko, 2005, was a preoccupied name (Opresko, 2011).

New collections from the region have become available as a result of the efforts of R. G. Stone of the Auk Bay Laboratories, NOAA Fisheries Service, Juneau, Alaska, and as a result of numerous research cruises conducted on NOAA vessels and by the Monterey Bay Aquarium Research Institute. Contained within these collections are the new species that are the subject of this report. A preliminary report on the deep-sea corals occurring off the coast of Alaska has been published by Stone \& Shotwell (2007), and a NOAA Professional Paper entitled "A Guide to the Corals of Alaska" by Stone et al. is in preparation and is scheduled for publication in 2022. The species discussed in the present paper will be included in the latter report, and the descriptions will be augmented with in situ photos.

\section{List of abbreviations and acronyms}

$\begin{array}{ll}\text { ABL } & \text { Auk Bay Laboratories (NOAA Fisheries Service, Alaska) } \\ \text { IORAS } & \text { P.P. Shirshov Institute of Oceanology, RAS (Moscow, Russia) } \\ \text { MBARI } & \text { Monterey Bay Aquarium Research Institute } \\ \text { mt } & \text { Mitochondrial (DNA) }\end{array}$




$\begin{array}{ll}\text { NHMUK } & \text { Natural History Museum, London, UK } \\ \text { NMNH } & \text { National Museum of Natural History, Smithsonian Institution } \\ \text { NOAA } & \text { National Oceanographic and Atmospheric Administration } \\ \text { ROV } & \text { Remotely operated vehicle } \\ \text { R/V } & \text { Research vessel } \\ \text { SEM } & \text { Scanning electron microscope } \\ \text { UCEs } & \text { Ultraconserved elements (of genomes) } \\ \text { USNM } & \text { Prefix for museum catalog numbers of the NMNH }\end{array}$

\section{Material and methods}

The specimens reported upon in this paper, including holotypes and paratypes, are deposited in the collections of the National Museum of Natural History (NMNH) or in the collection of the P.P. Shirshov Institute of Oceanology RAS, Moscow, Russia (IORAS). Also, for comparative purposes we studied type material of three species of the genus Bathypathes Brook, 1889 deposited in Natural History Museum, London, UK (NHMUK): Bathypathes patula Brook, 1889 (holotype, NHMUK 1890.4.9.19-20), B. patula var. plenispina Brook, 1889 (holotype, NHMUK 1890.4.9.18) and B. tenuis (syntypes, NHMUK 1890.4.9.24). Measurements of the gross features of the corallum and the polyps were made directly from the specimens or from photographs. The transverse diameter of the polyps was measured from the distal edge of the distal lateral tentacles to the proximal edge of the proximal lateral tentacles. The skeletal spines were examined using a Zeiss EVO MA 15 scanning electron microscope (SEM) housed at the NMNH. The specimens were coated with a $30-40 \mathrm{~nm}$ thick layer of $60 \%$ gold: $40 \%$ palladium prior to scanning. Measurements of the microscopic skeletal features were made using a dissecting microscope equipped with an ocular micrometer or from photographs taken with the SEM. By convention, the number of rows of spines is expressed as the number of rows that can be viewed on one side of the axis, also referred to as "seen from one aspect". The height of the spines was measured from the middle of the base to the apex. SEM stub numbers are from a series established by the first author at the NMNH and all SEM stubs are deposited at the NMNH.

\section{Results and discussion}

\section{Order Antipatharia Milne-Edwards, 1857}

\section{Family Schizopathidae Brook, 1889}

Diagnosis. Polyps elongated transversely; $2 \mathrm{~mm}$ or more in transverse diameter, with six primary and four secondary mesenteries. Corallum monopodial or branched; stem and branches pinnulate. Pinnules simple or complexly subpinnulate. Spines triangular to conical, simple or rarely with multiple bifurcations at apex, subequal in size around circumference of axis or larger on one side.

Remarks. This family is derived from the subfamily Schizopathinae, Brook, 1889, which originally contained the genera Schizopathes Brook, 1889, Bathypathes Brook, 1889, Taxipathes Brook, 1889, and Cladopathes Brook, 1889. In 1902 Roule elevated the subfamily to the family level and in 1905 established the family Parantipathidae Roule, 1905 for the genus Parantipathes Brook, 1889, which Brook had previously assigned to the subfamily Antipathinae Brook, 1889. Based on the differences in the transverse diameter of the polyps, Opresko (2002) recognized two subfamiles, the Schizopathinae containing the genera Schizopathes, Bathypathes, Stauropathes Opresko, 2002, Abyssopathes Opresko, 2002, Saropathes Opresko, 2002, and Dendrobathypathes Opresko, 2002, and the Parantipathinae containing the genera Parantipathes, Taxipathes and Lillipathes Opresko, 2002. In recent DNA studies using the mitochondrial (mt) gene regions cox-coxl and nad5-nad1, Chery et al. (2018) found that representatives of the genera Bathypathes, Stauropathes and Telopathes MacIsaac \& Best, 2013, grouped together into one clade and all the other genera in the family, including Parantipathes and Schizopathes, the nominate genus of the family, fell into a sister group. Based on complete mitochondrial genomes, Barrett et al. (2020) reported a similar close grouping between representatives of the North-Atlantic genera Bathypathes, Stauropathes and Telopathes, 
that formed a sister clade with Parantipathes spp.; however, Schizopathes was not included in the analysis. In contrast, in a study using ultraconserved elements (UCEs) of genomes, Horowitz et al. 2020), found that a specimen of Schizopathes affinis Brook, 1889, grouped with two specimens of Bathypathes patula in a clade that also included a specimen of Telopathes. Samples of Parantipathes were not included in that analysis. Further study is needed to clarify the relationships between the genera currently assigned to the family.

\section{Alternatipathes Molodtsova and Opresko, 2017 (emended)}

Alternatipathes Molodtsova \& Opresko, 2017: 358 (see synonymy therein).

Diagnosis. Corallum attached to substrate; monopodial, unbranched or with a few basal branches, and pinnulate. When present, pinnate branches of first order develop from lowermost pinnules of stem. Pinnules simple, arranged alternately (including lowermost pair) in two lateral rows. Length of pinnules on stem and branches decreasing in a distal direction, forming a triangularly shaped outline. Striatum absent. Spines conical, smooth, simple (or rarely forked), with acute to slightly rounded apex and flared base. Spines larger on polypar side of pinnule. Polyps 2-7 $\mathrm{mm}$ in transverse diameter.

Type species. Umbellapathes bipinnata Opresko, 2005.

Remarks. The diagnosis of the genus has been emended to account for the larger polyps found in the new species described below.

The genus Alternatipathes was established by Molodtsova and Opresko (2017) based on corallum morphology (alternating pinnules and stem lacking a fluted region referred to as a striatum) and the results of mt DNA sequencing studies using cox3-coxl (Brugler et al. 2013), which indicated that Umbellapathes bipinnata Opresko, 2005, and an undescribed Umbellapathes species (USNM 1204042, see Brugler et al. 2013, figures 2 and 3) were genetically distant from both Bathypathes and Schizopathes. More recent DNA sequencing studies using the $\mathrm{mt}$ gene regions, cox3-cox1 and nad5-nad1 (Chery et al. 2018) support the separation of A. bipinnata from Schizopathes; however, several unbranched specimens morphologically similar to Alternatipathes grouped with Schizopathes. Further study is needed to determine the parameters that separate Alternatipathes from Schizopathes.

Species assigned to the genus. Umbellapathes bipinnata Opresko, 2005, Bathypathes alternata Brook, 1889, Alternatipathes venusta Opresko \& Wagner, 2020, and Alternatipathes mirabilis n. sp.

Distribution. The genus occurs in the Pacific, Indian, Atlantic and Southern Oceans at depths usually exceeding $2500 \mathrm{~m}$ and often greater than $4000 \mathrm{~m}$. Information regarding occurrences in the Southern Ocean (mostly Bellingshausen/Amundsen Abyssal plains) are based on unpublished R/V Eltanin records at the NMNH [e.g., USNM 1114499 (R/V Eltanin sta. 673); USNM 78806 and USNM 83545 (R/V Eltanin sta. 1140); and USNM 78811 (R/V Eltanin sta. 1640)].

\section{Alternatipathes mirabilis n. sp.}

(Fig. 1)

urn:lsid:zoobank.org:act:C810F528-71BD-4604-A08F-5180236EDCB8

Material examined. Holotype: USNM 1070972 (SEM stubs 451 and 488), North Pacific, Derickson Seamount, $53.0419^{\circ} \mathrm{N}, 161.1830^{\circ} \mathrm{W}$, ROV Jason II, Dive 93 (Field Identification Number: JD-093), 4685 m, coll. A. BacoTaylor, 20 July 2004.

Diagnosis. Colony attached, monopodial, unbranched, and pinnulate. Pinnules simple, arranged alternately in two lateral rows along upper part of stem. Lower unpinnulated section of the stem longer than upper pinnulated section. Pinnules generally decreasing in length proximally to distally. Pinnular density 10-11 per $3 \mathrm{~cm}$ (including pinnules in both rows). Spines on pinnules smooth, triangular in profile, moderately acute, laterally compressed, and mostly $0.04-0.06 \mathrm{~mm}$ tall on polypar side of axis. Polyps on pinnules mostly 5-7 $\mathrm{mm}$ in transverse diameter, with four to five polyps per $3 \mathrm{~cm}$.

Description of the holotype. The holotype (USNM 1070972, Fig. 1A) is an almost complete colony with an intact basal holdfast; the very tip of the stem, however, is broken off. The stem is about $46.5 \mathrm{~cm}$ long with a basal 
diameter of $2.4 \mathrm{~mm}$. The lower unpinnulated section of the stem is $32.5 \mathrm{~cm}$, and the upper pinnulated section covers a distance of $14 \mathrm{~cm}$. The pinnules are simple, bilateral and alternately arranged; generally decreasing in length from the lower part of pinnulated stalk to the distal end. Most of the pinnules are broken off at the end; the longest remaining ones are about $15 \mathrm{~cm}$ in length with a basal diameter of about $0.8 \mathrm{~mm}$. Forty-six pinnules occur on the corallum, 23 on each side of the stem. Within each row, the pinnules are spaced 5-6 mm apart. The resulting pinnular density is 10 (total for both rows) per $3 \mathrm{~cm}$ near the basal end of the stem to about 11 per $3 \mathrm{~cm}$ in the middle and towards the distal end. In the preserved specimen the lower rows of pinnules form an interior angle of about $60^{\circ}$, which increases towards the top of the corallum to $180^{\circ}$. The distal angle that the pinnules form with the stem is $60-80^{\circ}$, even at the top of the corallum.

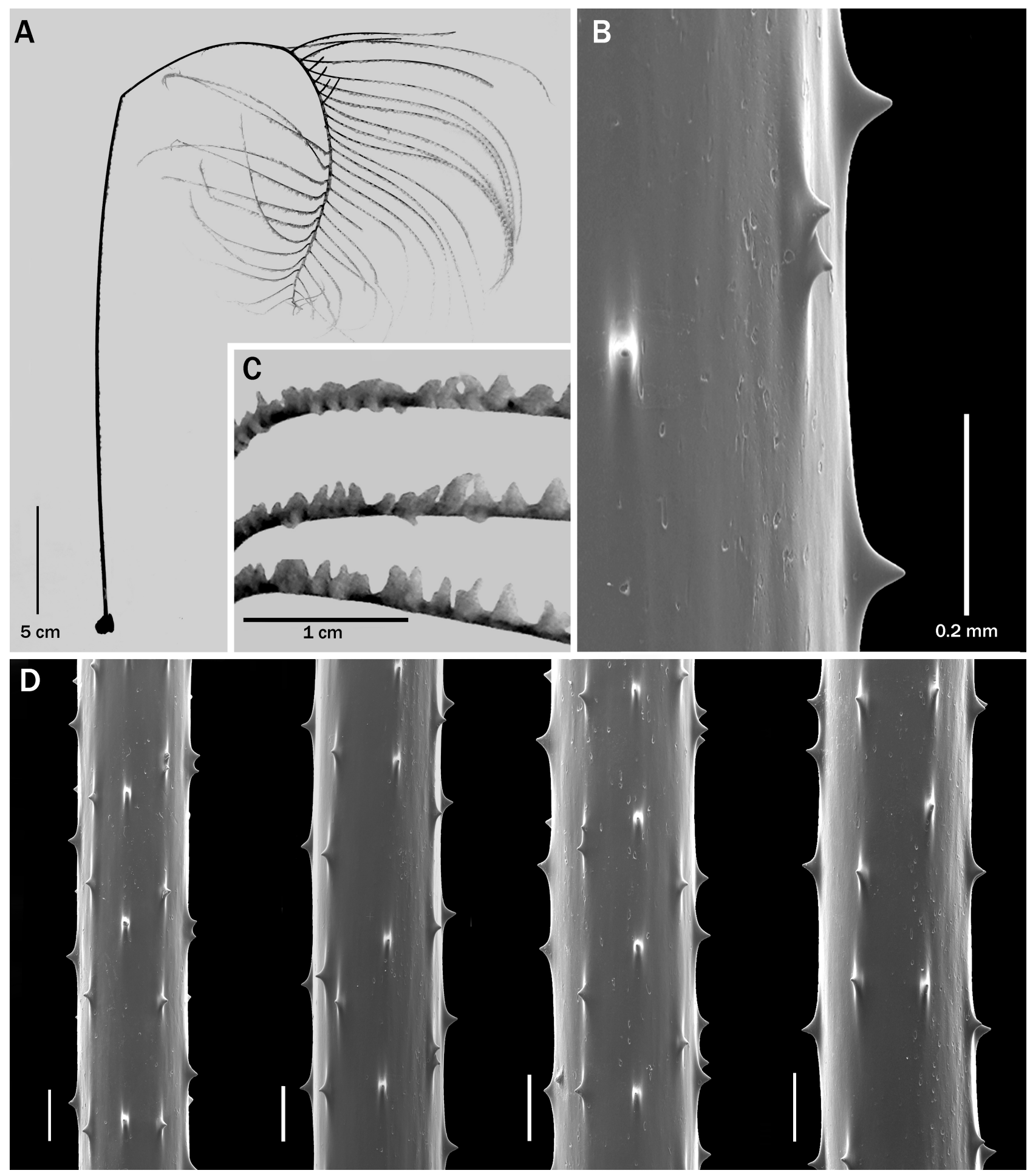

FIGURE 1. Alternatipathes mirabilis n. sp., holotype, USNM 1070972: A. corallum; B. enlarged view of spines; C. polyps; D. sections of pinnules showing spines, scale bars $0.2 \mathrm{~mm}$ (B and D from SEM stub 488). 
The spines on the pinnules are very small, triangular in profile, moderately acute, smooth, and laterally compressed (Fig. 1B, 1D). There is only a slight difference in the size of the polypar and abpolypar spines. On sections of pinnules about $0.4 \mathrm{~mm}$ in diameter the polypar spines are mostly $0.04-0.047 \mathrm{~mm}$ tall (maximum $0.06 \mathrm{~mm}$ ) and the abpolypar spines are $0.03-0.04 \mathrm{~mm}$ tall. Double spines are present, but are not common. The central axial canal is $0.31 \mathrm{~mm}$ in diameter on a pinnule $0.43 \mathrm{~mm}$ in diameter. Five or six axial rows are visible in lateral view, and a few individual spines occur randomly between the rows. In each row the spines are a variable distance apart, 0.26 to 0.79 $\mathrm{mm}$; however, on average, there are 2.5-3.5 spines per $\mathrm{mm}$ in each axial row. The spines on the stem are similar to those on the pinnules in size and shape.

The polyps (Fig. 1C) occur in a single series on one side of the pinnules; they are 5-7 $\mathrm{mm}$ in transverse diameter. Near the distal end of the pinnules there are four polyps per $3 \mathrm{~cm}$, and in the mid to basal sections of the pinnules there are up to five polyps per $3 \mathrm{~cm}$.

Other material. No other specimens can be assigned to the species at this time.

Genetic data. DNA analysis (nad5-nad1) of the holotype (USNM 1070972) suggests a close relationship to Schizopathes (Chery et al. 2018); however, further study is needed.

Comparisons. Alternatipathes mirabilis $\mathbf{n}$. sp. differs from the type species of the genus, A. bipinnata, in that it does not form branches; it has longer pinnules $(15 \mathrm{~cm}$ vs. $4.5 \mathrm{~cm})$; much smaller spines $(0.04-0.06 \mathrm{~mm}$ vs. up to 0.3 $\mathrm{mm}$ ); much larger polyps (5-7 mm vs. 2-3 mm); and a lower polyp density (4-5 per $3 \mathrm{~cm}$ vs. about 9 per $3 \mathrm{~cm}$ ).

Alternatipathes mirabilis $\mathbf{n}$. sp. differs from specimens assigned to A. alternata in having: 1 ) relatively thicker pinnules ( $0.8 \mathrm{~mm}$ vs. $0.5 \mathrm{~mm}$ basal diameter for pinnules $13-15 \mathrm{~cm}$ long); 2$)$ a wider central axial canal ( $0.3 \mathrm{~mm}$ vs. $0.12-0.18 \mathrm{~mm}$ on pinnules $0.22-0.25 \mathrm{~mm}$ in diameter, excluding spines); 3 ) less of a difference in the relative sizes of the polypar and abpolypar spines (about one-third larger in A. mirabilis vs. more than twice as large in A. alternata); 4) relatively longer pinnules $(15 \mathrm{~cm}$ or more vs. $10.5 \mathrm{~cm})$ on colonies having pinnulated sections of similar length $(13 \mathrm{~cm}$ vs. $11 \mathrm{~cm}) ; 5)$, a wider distal angle of the pinnules at the top of the corallum $\left(60-80^{\circ} \mathrm{vs} .45^{\circ}\right.$ or less) and 6) larger polyps (5-7 mm vs. 3-4 $\mathrm{mm}$ in transverse diameter), resulting in a smaller polyp density (4-5 vs. 6-8 per $3 \mathrm{~cm}$ ). However, it is important to note that these comparisons are based on a single specimen that is currently assigned to Alternatipathes mirabilis; thus, the ranges reported for this species should not be considered absolute.

Alternatipathes mirabilis $\mathbf{n}$. sp. differs from specimens assigned to $A$. venusta in that it has a wider distal angle of the pinnules at the top of the corallum $\left(60-80^{\circ}\right.$ vs. $\left.30^{\circ}\right)$, no difference between polypar and abpolypar spines, much shorter pinnular spines $(0.04-0.06 \mathrm{~mm}$ vs. $0.11-0.22 \mathrm{~mm})$; slightly larger polyps (5-7 mm vs. $3.5-5 \mathrm{~mm})$; and a lower polyp density ( $4-5$ per $3 \mathrm{~cm}$ vs. about $6-8$ per $3 \mathrm{~cm}$ ).

Etymology. The species name is derived from the Latin, mirabilis, meaning "wonderful or strange".

Distribution. Known only from a single specimen collected in the North Pacific at a depth of $4685 \mathrm{~m}$.

\section{Bathypathes Brook, 1889 (emended)}

partim Bathypathes Brook, 1889: 151; Thomson 1905: 76-79; van Pesch 1914: 27; Pasternak 1958: 180-181; 1977: 157; Opresko 2002: 415; Brugler et al., 2013: 317; MacIsaac et al., 2013: 241-243; Molodtsova 2006: 141; Molodtsova $2014: 5$. Bathypathes, Horowitz et al., 2018: 312. partim Schizopathes Brook, 1889: 146-147, 150.

Diagnosis. Corallum attached to substrate; monopodial, unbranched or rarely with a branch forming where the corallum has been broken and is regenerating. Pinnules simple, arranged alternately or suboppositely in two anterolateral or lateral rows. Length of pinnules on stem and branches usually longest near the middle of the pinnulated section of the corallum. Striatum present or absent. Spines conical, smooth, simple, forked or multiply knobbed at apex, with acute to slightly rounded apex. Spines often larger on polypar side of axis than on abpolypar side. Polyps from $2 \mathrm{~mm}$ to as much as $17 \mathrm{~mm}$ in transverse diameter.

Type species. Bathypathes patula Brook, 1889 (see Fig. 2A-B).

Remarks. The genus Bathypathes is very close morphologically to Stauropathes in that most species have bilateral, subopposite pinnules, a characteristic which is typical for all species of Stauropathes. In general, the members of the pairs of pinnules are more offset in Bathypathes and in some species they are even alternately arranged. Species of Bathypathes are monopodial without branches or subpinnules and with simple pinnules originating from the stem, whereas in Stauropathes the pinnules on the stem are usually pinnulated themselves, thus forming 
branches. In recent DNA sequencing studies using the $\mathrm{mt}$ gene region nad5-nadl (Chery et al. 2018) the two genera were not clearly separable; however, in an analysis with cox3-cox1 all four specimens of Stauropathes fell into a single subclade, along with one typical Bathypathes species, whereas all six other Bathypathes specimens analyzed fell into a separate subclade.

The diagnosis of the genus is herein emended as a result of the transfer of the species Bathypathes alternata Brook to the genus Alternatipathes Molodtsova \& Opresko, 2017. In contrast to the genera Alternatipathes and Schizopathes, that have a triangular-shaped pinnulated section with the basal pinnules being the longest and the pinnules gradually decreasing in length toward the top of corallum, all hitherto known species of the genus Bathypathes usually have the longest pinnules near the middle of the pinnulated section of the corallum and the pinnules have approximately the same length for some distance.
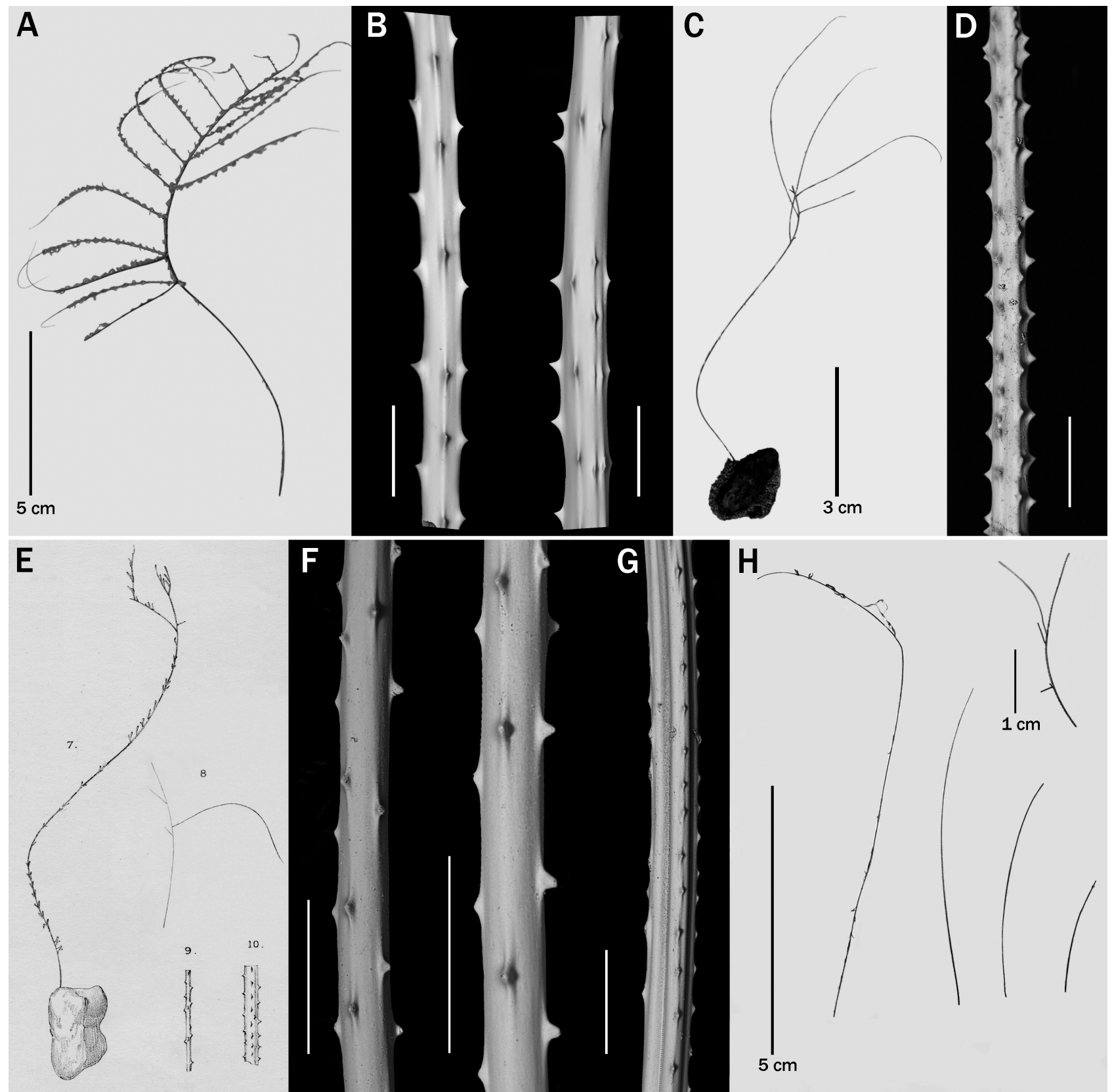

FIGURE 2. Bathypathes spp.: A. probable holotype of B. patula Brook (NHMUK 1890.4.9.19-20); B. sections of pinnules of specimen shown in A; C. holotype of B. plenispina Brook (NHMUK 1890.4.9.18); D. section of pinnule of the specimen shown in C; E. digital scan of original figure of B. tenuis Brook; F. two sections of pinnules from type material of B. tenuis; G. section of stem of type material of $B$. tenuis; H. current condition of type material of $B$. tenuis Brook (NHMUK 1890.4.9.24). Scale bars $0.5 \mathrm{~mm}$ in $\mathrm{B}, \mathrm{D}, \mathrm{F}$, and $\mathrm{G}$. 
Species assigned to the genus. Bathypathes bayeri Opresko, 2001; B. bifida Thompson, 1905; Schizopathes conferta Brook, 1889; B. erotema Schultze, 1903; B. galathea Pasternak, 1977; B. patula Brook, 1889; Stichopathes robusta Gravier, 1918 (see Molodtsova 2014); B. platycaulus Totton, 1923; B. patula var. plenispina Brook, 1889 (see Fig. 2C-D); B. ptiloides n. sp.; B. tenuis Brook, 1889 (see Fig. 2E-H); B. tiburonae n. sp.; and B. alaskensis n. sp. Note: $B$. patula var. plenispina is here recognized as a distinct species, $B$. plenispina, based on more densely set pinnules (6-7 mm apart vs. $10 \mathrm{~mm}$ apart in B. patula), upright conical spines with little difference in the size of the polypar and abpolypar spines (compare Fig. 2B and 2D), and a greater density of the spines on the pinnules (4-5 per mm vs. 3 per $\mathrm{mm}$ ).

Except for B. platycaulus, all nominal species have subopposite pinnules. Bathypathes seculata is now considered a junior synonym of $B$. patula (see Horowitz et al. 2018), and Bathypathes erotema may be a junior synonym of $B$. plenispina (or B. tenuis) but with more densely arranged pinnules and larger spines. Bathypathes tenuis was previously thought to belong in the genus Umbellapathes based on the fact that in the original description (Brook 1889, p.155) and original illustration (see Fig. 2E) it was reported to have secondary pinnules (Opresko 2005). Museum records indicate that over the years the type material (NHMUK 90.4.9.24) dried out and was subsequently rehydrated in 1987. When later re-examined, the remaining type material consisted only of five pieces (Fig. 2H), none of which possessed secondary pinnules. Examination of sections of the stem revealed the presence of a structural modification (Fig. 2G), resembling a striatum, which is typical of the genus Bathypathes. Unfortunately, this species is only known from the now incomplete and damaged type material of what were most likely juvenile specimens; therefore, further evaluation of the affinities of the species is not possible at this time, and the species for now must be considered incertae sedis. Future genetic evaluation of any remaining soft tissue on the type material might resolve the issue.

Distribution. The genus occurs in the Pacific, Indian, Atlantic and Southern Oceans at depths of 102-5393 m. The shallowest distribution record for the genus (Bathypathes patula var. plenispina from Burdwood Bank, Scotia Sta. 346, 56 fathoms) was reported by Thomson (1905); however, there are serious concerns as to whether this species really occurred at such a shallow depth considering that the type was originally reported from a depth of 1070 fathoms $(1956.8 \mathrm{~m})$. It is possible that the lot was mislabeled.

\section{Bathypathes ptiloides n. sp.}

(Fig. 3)

urn:lsid:zoobank.org:act:5CDAF402-E496-429F-91CA-A444396A4AB2

Bathypathes sp. Brugler et al. 2013: 327, 330, fig. 2, fig. 3, fig. 5; Horowitz et al., 2020: 559, fig.3a.

Material examined. Holotype: USNM 1070974 (SEM Stubs 205 and 410), N. Pacific, Derickson Seamount, 53.1175 $\mathrm{N}, 161.3000^{\circ} \mathrm{W}$, ROV Jason II, Dive 94 (Field Identification Number: JD-094, spec. \#4), $4664 \mathrm{~m}$, coll. A. Baco-Taylor, 23 July 2004. Other Material: USNM 1071408, N. Pacific, Derickson Seamount, 53.1117 ${ }^{\circ}$, 161.2990 W, ROV Jason II, Dive 94 (Field Identification Number: JD-094, spec. \#8), 4477 m, coll. A. Baco-Taylor, 23 July 2004.

Diagnosis. Colony monopodial and pinnulate; pinnules simple, arranged along the stem in two lateral or anterolateral rows and in subopposite pairs. Pinnular density 6-8 per $3 \mathrm{~cm}$. Unpinnulated stalk up to $66 \mathrm{~cm}$ long; pinnulated section about $10 \mathrm{~cm}$ long. Spines simple, smooth, triangular, up to $0.04 \mathrm{~mm}$ tall on the polyp side of the axis; with five to six rows visible in lateral view. Polyps arranged uniserially; mostly 6-7 $\mathrm{mm}$ (up to $8 \mathrm{~mm}$ ) in transverse diameter on pinnules, with 3 to 3.5 polyps per $3 \mathrm{~cm}$.

Description of the holotype. The corallum of the holotype (USNM 1070974) consists of a very long unpinnulated stalk topped by a short pinnulated section (Fig. 3A). An in situ photo (Fig. 3B) indicates that the lower section of the stem was tilted forward towards the polyp side of the colony and at the about half the distance to the pinnulated section it was more strongly curved in the same direction after which it curved back such that the upper part of the pinnulated section is almost vertical. As measured on the preserved specimen, which is now in three sections and broken off at the top, the length of the entire stem is about $76 \mathrm{~cm}$. The unpinnulated portion of the stem is $66 \mathrm{~cm}$ long and the pinnulated portion covers the remaining $10 \mathrm{~cm}$, including the broken off tip. The maximum width of the corallum across the pinnulated section is approximately $15 \mathrm{~cm}$, and the basal diameter of the stem is 1.6 by $2 \mathrm{~mm}$ (the 
holdfast was not collected). There is no visible striatum on the stem. The pinnules are arranged in subopposite pairs. Viewing the polyp side of the corallum, the left pinnule of each pair (except for one) is inserted on the axis about 3 $\mathrm{mm}$ lower than the opposite member for the lower pairs and about $2 \mathrm{~mm}$ apart for the more distal pairs. Most of the pinnules are broken off at the distal end; the longest remaining pinnule is about $12 \mathrm{~cm}$ in length and $0.6 \mathrm{~mm}$ in basal diameter. Photos taken in situ suggest that the longest pinnules were those in the third distal pair from the bottom after which the pinnules gradually decrease in length towards the top of the corallum. The pinnules are spaced 6-13 $\mathrm{mm}$ apart in each lateral row, and, on average, there are three pairs per $3 \mathrm{~cm}$ on the lower pinnulated portion of the stem and four pairs per $3 \mathrm{~cm}$ higher up. The pinnules are inclined distally such that the distal angle they form with the stem is $70-80^{\circ}$. The interior angle formed by the two rows of pinnules is $120^{\circ}$ or more. The spines (Fig. 3D-E) are simple, smooth, triangular, compressed, with a rounded apex and a base that extends out in a very shallow slope in both the distal and basal directions. On sections of pinnules $0.5-0.7 \mathrm{~mm}$ in axial diameter, the polypar spines are $0.04 \mathrm{~mm}$ tall and the abpolypar spines $0.035 \mathrm{~mm}$. The spines are arranged in axial rows, five or six of which are usually visible in one lateral view. Within the rows the spines are spaced irregularly, $0.3-0.6 \mathrm{~mm}$ apart, but on average there are 3 or 4 spines per mm. The polyps (Fig. 3C) are uniserially arranged on one side of the stem and on the same side of the pinnules. The polyps on most parts of the pinnules are 6-7 $\mathrm{mm}$ in transverse diameter (measured from the distal edge of the distal lateral tentacles to the proximal edge of the proximal lateral tentacles), although the range varies from about 5 to $8 \mathrm{~mm}$ depending on the state of contraction. The density of the polyps in the middle of the pinnules is mostly 3 to 3.5 per 3 centimeters. On the stem the polyps are $7 \mathrm{~mm}$ in transverse diameter.

Description of other material. The other specimen assigned to this species is USNM 1071408. Field notes indicate that the unpinnulated section of the stem and the holdfast were not collected, but most of the upper pinnulated part of the colony was collected; however, only a small vial containing several pinnules was found in the NMNH collection. One of the pinnules is about $15 \mathrm{~cm}$ long and $1.8 \mathrm{~mm}$ in diameter. In situ photos (Fig. 3F) indicate that the intact colony was quite large, the stem somewhat S-shaped in lateral view, with a basal unpinnulated stalk estimated to be 50-60 cm long, and with an upper pinnulated section at least $25 \mathrm{~cm}$ in length. It was also estimated from the in situ photo that on the lower part of the pinnulated section there were about eight pinnules total per $5 \mathrm{~cm}$ and perhaps up to 15 pinnules total per $10 \mathrm{~cm}$, and that the longest pinnules were $25-30 \mathrm{~cm}$ in length. On one of the pinnules retained, the spines are $0.03 \mathrm{~mm}$ tall, and the polyps are up to $8 \mathrm{~mm}$ in transverse diameter, with about three polyps per $3 \mathrm{~cm}$. These measurements fall within the ranges of those for the holotype.

Genetic data. GenBank Acc. Nos.: USNM 1070974 [KF054479 (igrW); KF054612 (igrN); and KF054371 (cox3-cox1)] (Brugler et al. 2013).

Brugler et al. (2013, Suppl. Table S1) sequenced the mt gene regions trnW-nad2, nad5-nad1, and cox1 of the holotype of B. ptiloides n. sp. (USNM 1070974) and found that all three haplotypes were different from the corresponding haplotypes of six specimens of Bathypathes alaskensis n. sp. Furthermore, two of the haplotypes were unique when compared to those of four other Bathypathes morphotypes. [Note: a phylogenetic tree for the nad5nadl $(=i g r N)$ results in Brugler et al. (2013), is presented in Horowitz et al. (2020)]. The holotype of B. ptiloides was also one of thirteen Bathypathes specimens that Chery et al. (2018) analyzed using the mt gene regions cox3coxl and nad5-nad1. For the gene region cox3-coxl the holotype was found to have a unique haplotype that did not match that of any of the other specimens analyzed, including the holotype of B. tiburonae n. sp. For the gene region nad5-nad1, the B. ptiloides holotype was genetically distinct from all the other Bathypathes species analyzed (including the holotype of B. tiburonae as well as a specimen identified in Chery et al. (2018) as Bathypathes. sp. (USNM 1453622) which we have identified as B. patula.)

Comparisons. Bathypathes ptiloides n. sp. differs from B. platycaulus by having subopposite pinnules, and from $B$. bifida by having more than one pair of pinnules. By its relatively short pinnular spines (up to $0.04 \mathrm{~mm}$ ) $B$. ptiloides differs from $B$. bayeri, B. conferta, B. galathea and herein described B. alaskensis $\mathbf{n}$. sp. and B. tiburonae n. sp., all of which have pinnular spines $>0.08 \mathrm{~mm}$. Bathypathes ptiloides $\mathbf{n}$. sp. resembles B. erotema, B. patula (Fig. 2A-B), B. plenispina (Fig. 2C-D) and B. tenuis (Fig. 2E-H) in having a simple monopodial colony with subopposite pinnules, short triangular and smooth pinnular spines and moderate size polyps $(5-7 \mathrm{~mm})$, but differs from all these species in that the stalk is much longer $(66 \mathrm{~cm}$ in the holotype vs. about $10 \mathrm{~cm}$ in the types of B. patula, B. erotema and $B$. tenuis), and there are more rows of spines visible in lateral view (5-6 vs. 3-5). The differences in the length of the stalk are also reflected in differences in the ratio of the length of the stalk to that of pinnulated section for colonies having pinnulated sections of similar length. For example, in both the type of B. patula and $B$. ptiloides the upper pinnulated section is about $10 \mathrm{~cm}$; therefore, the ratio is $6: 1$ for $B$. ptiloides, but only $1: 1$ for $B$. 
patula. Other differences between the types of these two species are in the relative length of the pinnules; the longest pinnules are slightly longer in B. ptiloides (more than $12.5 \mathrm{vs} .7 .5 \mathrm{~cm}$ ) even though the pinnulated sections are similar in length, and in the size of the pinnular spines which are slightly smaller in B. ptiloides (up to $0.04 \mathrm{~mm}$ vs. up to $0.07 \mathrm{~mm}$ in B. patula).

Etymology. Species name "ptiloides" is derived from the Greek ptilon (feather) and the suffix oides (like), an illusion to the general shape of the corallum.

Distribution. North Pacific, Derickson Seamount, at depths of 4477-4664 m.
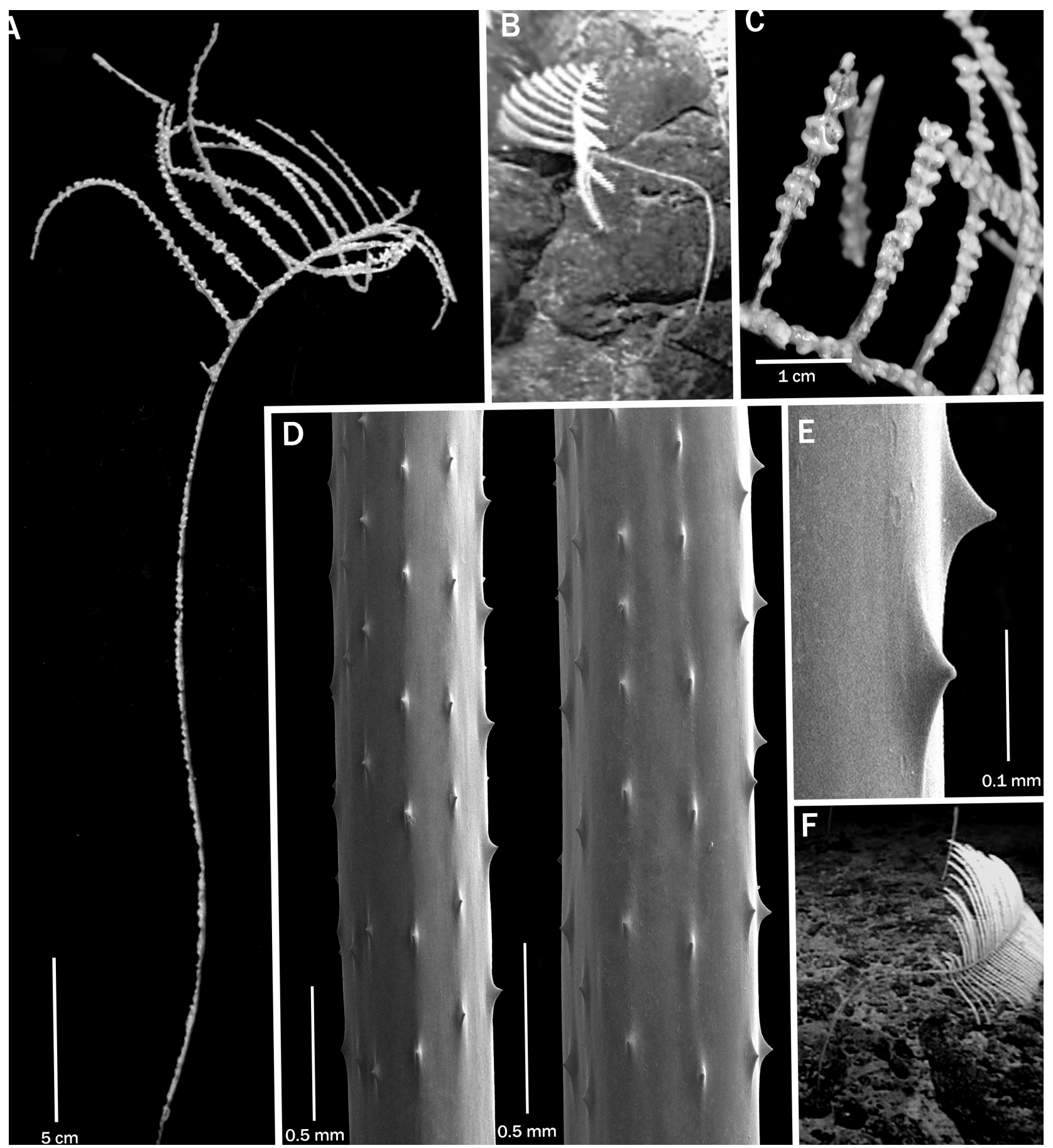

FIGURE 3. Bathypathes ptiloides n. sp.: A-E, holotype, USNM 1070974: A. corallum (lower section of stem not shown); B. in situ photo; C. polyps; D. sections of pinnules showing spines, from SEM stub 410; E. close-up view of spines, from SEM stub 410; F. in situ photo of USNM 1071408. 


\section{Bathypathes tiburonae n. sp.}

(Fig. 4)

urn:lsid:zoobank.org:act:8901BBD9-21F8-4C8A-B266-2207CBF942C0

Material examined. Holotype: USNM 1116837 (SEM stub 251), North Pacific, off California, Gorda Transform, $41.6688^{\circ} \mathrm{N}, 127.3090^{\circ} \mathrm{W}, \mathrm{R} / \mathrm{V}$ Western Flyer, ROV Tiburon, Dive 193, Sample No. W-193-A1, $3121.2 \mathrm{~m}$, MBARI, 1 Mar 2006. Paratype: USNM 1234549, North Pacific, Gorda Ridge, off Oregon, $42.6690^{\circ} \mathrm{N}, 126.7850^{\circ} \mathrm{W}, \mathrm{R} / \mathrm{V}$ Western Flyer, ROV Tiburon, Dive 886, Sample No. T886 A7, 3150.2 m, MBARI, 25 Aug 2005. Other material: USNM 1459868, North Pacific, Gulf of Alaska, $53.2911^{\circ} \mathrm{N}, 164.0460^{\circ} \mathrm{W}$, ROV Jason II, Dive 87 (Field Identification Number: JD-087), 3356 m, coll. A. Baco-Taylor, July 2004.

Diagnosis. Colony monopodial and pinnulate; pinnules simple, arranged along the stem in two anterolateral rows and in subopposite pairs. Stem up to $55 \mathrm{~cm}$ in length. Pinnules spaced 10-18 mm apart (density 4-6 per 3 $\mathrm{cm}$ ). Spines simple, smooth, triangular; polypar spines up to $0.09 \mathrm{~mm}$ tall on the pinnules. Polyps uniserially arranged on one side of corallum, up to $12 \mathrm{~mm}$ in transverse diameter on the pinnules, with about three polyps per 4 centimeters.

Description of holotype. The holotype (USNM 1116837) is about $55 \mathrm{~cm}$ tall and has a maximum width of $30 \mathrm{~cm}$ about $3 \mathrm{~cm}$ above the start of the pinnulated section. The basal stem diameter is $3 \mathrm{~mm}$ at a distance about $3 \mathrm{~mm}$ above the holdfast which is intact (Fig. 4A). The unpinnulated portion of the stem is about $37 \mathrm{~cm}$ long; the pinnulated portion covers the remaining $18 \mathrm{~cm}$. A striatum is present on the stem; it starts $16 \mathrm{~cm}$ above the base and extends for $6 \mathrm{~cm}$. The pinnules are arranged in subopposite pairs (11 pairs in all), the left pinnule of each pair (viewing the polyp side of the corallum) is inserted on the axis about $3 \mathrm{~mm}$ lower than the subopposite member (as measured from the middle of the pinnules; $1-2 \mathrm{~mm}$ as measured from the nearest edges of the subopposite pinnules) for all but one of the pairs where the arrangement is reversed. Most of the pinnules are broken off at the distal end; the longest pinnule on the corallum is $17 \mathrm{~cm}$ in length and $0.9 \mathrm{~mm}$ in basal diameter; it is in the third pair distal from the most basal ones. The pinnules appear swollen near their proximal end, and the diameter of the central axial canal is more than three-quarters of the width of the pinnule. In each row, the pinnules are spaced about 13-18 mm apart on the lower section of the corallum and about $13 \mathrm{~mm}$ apart on the upper section. There are two pairs of pinnules per $3 \mathrm{~cm}$ on the lower part of the stem and up to three pairs per $3 \mathrm{~cm}$ on the upper part. The pinnules are inclined slightly, such that the distal angle with the stem is about $80^{\circ}$. The interior angle formed by the two rows of pinnules near their point of origin on the stem is $120^{\circ}$ or more. The spines are simple, smooth, triangular, compressed, with a rounded apex (Fig. 4C). On pinnules about $0.5 \mathrm{~mm}$ in axial diameter, the polypar spines are $0.06-0.09 \mathrm{~mm}$ tall and the abpolypar spines are $0.05-0.08 \mathrm{~mm}$. The spines are arranged in rows, usually five of which (rarely six) are visible in one lateral view. Within the rows the spines are spaced irregularly, $0.12-0.52 \mathrm{~mm}$ apart; the spine density is usually around three per millimeter (range 2-4 per $\mathrm{mm}$ ). In places the spines undergo splitting; eventually forming double spines. Spines occur along low ridges on the proximal, thicker part of the pinnules. The polyps (Fig. 4B) are uniserially arranged on one side of the stem and on the same side of the pinnules. The polyps on the pinnules are mostly 9-12 $\mathrm{mm}$ in transverse diameter as measured from the distal edge of the distal lateral tentacles to the proximal edge of the proximal lateral tentacles; the interpolypar space is $2-3 \mathrm{~mm}$, and there are three polyps per $4 \mathrm{~cm}$ or four to five polyps in $5 \mathrm{~cm}$. The polyps on the stem are up to $1.7 \mathrm{~cm}$ in transverse diameter, with two polyps per $4 \mathrm{~cm}$.

Description of paratype and other material. The paratype (USNM 1234549) is similar to the holotype in having subopposite pinnules, large polyps, relatively long pinnules, and moderately large polypar spines. It consists only of the upper $7 \mathrm{~cm}$ of a colony (with the growing tip intact) with the equivalent of five pairs of pinnules (several pinnules are missing on one side of the stem). The length and thickness of the pinnules $(18-24 \mathrm{~cm}$ and $0.8 \mathrm{~mm}$ in basal diameter) are similar to those of the holotype. Based on the length of pinnules of the fragment collected, the length of the unpinnulated stalk can be estimated to be $25-30 \mathrm{~cm}$; however, in contrast to the holotype, the complete colony, as could be seen in an in situ photo, had a longer pinnulated section with at least 17 pairs of pinnules. The axial canal is about two-thirds the width of the pinnule near the distal end, but is not visible at the lower basal part of the pinnule. The subopposite pinnules are offset by about $1.5 \mathrm{~mm}$. The spacing of the pinnules in each lateral row of the collected fragment is quite variable, $1-1.7 \mathrm{~cm}$ apart, and there is the equivalent of six pinnules total per $3 \mathrm{~cm}$. On sections of pinnules $0.5-0.7 \mathrm{~mm}$ in diameter, the polypar spines are $0.07-0.09 \mathrm{~mm}$ tall, and five to seven rows are visible in lateral view. Within each row the mutual distance is very variable $(0.12-0.45 \mathrm{~mm})$, but, on average, there are $3-4$ per $\mathrm{mm}$. The polyps are $10-11 \mathrm{~mm}$ in transverse diameter in the middle of the pinnules, with four polyps occurring along a $4.5 \mathrm{~cm}$ length of pinnule. 
USNM 1459868 consists only of a few pinnules; however, the polyps (9-10 $\mathrm{mm}$ in transverse diameter with 2.5 per $3 \mathrm{~cm})$ and spines $(0.066-0.08 \mathrm{~mm})$ are very similar in size to those in the holotype.

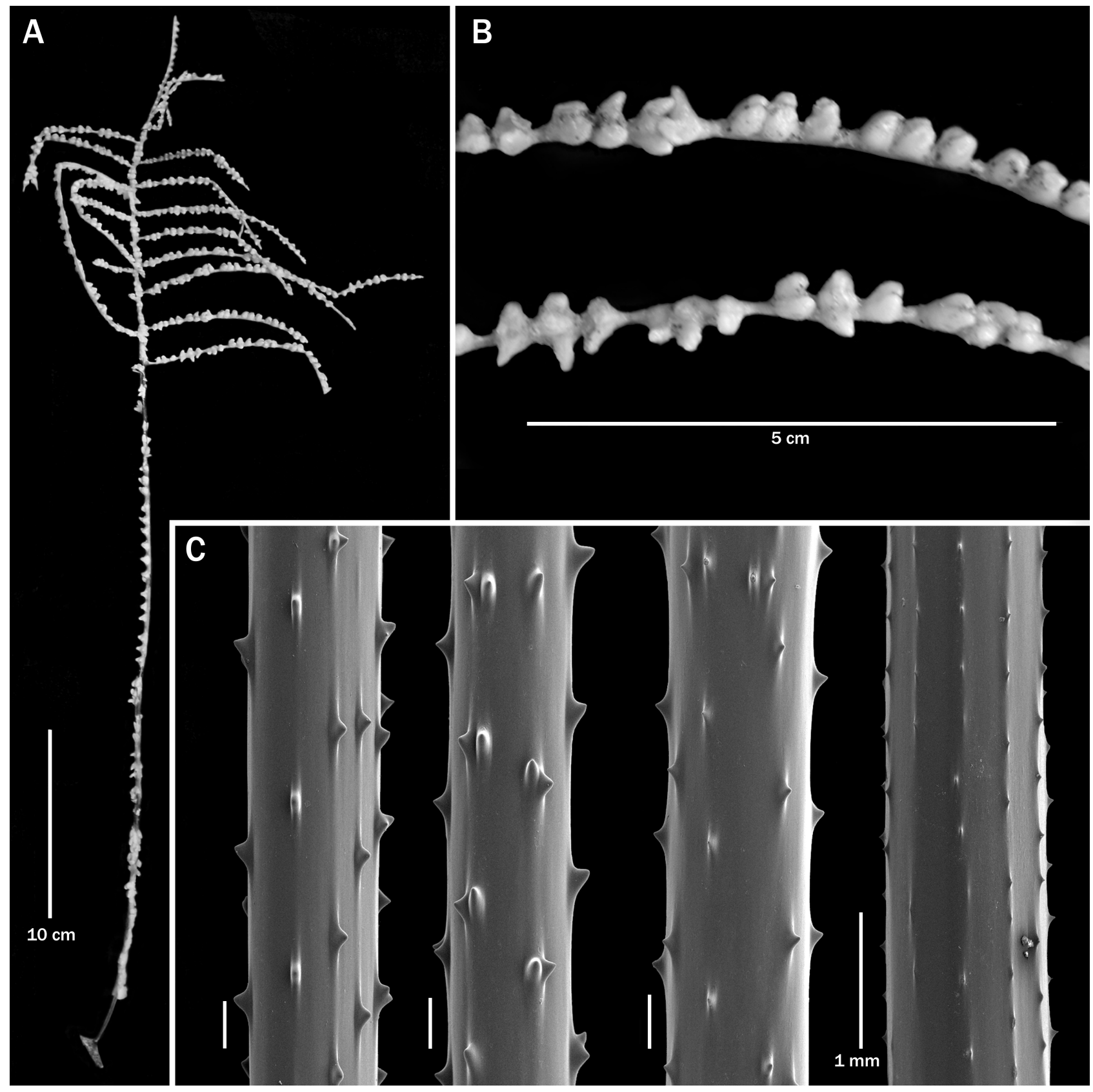

FIGURE 4. Bathypathes tiburonae n. sp., holotype, USNM 1116837: A. corallum; B. polyps; C. three sections of pinnules and one section of stem (far right) showing spines; scale bars $0.2 \mathrm{~mm}$ except as indicated. (C from SEM stub 251).

Genetic data. In DNA sequencing studies (Chery et al. 2018) using the mt gene region nad5-nad1, two of the specimens assigned to this species, the paratype of $P$. tiburonae (USNM 1234549) and USNM 1459868 had identical haplotypes, and this haplotype was different from the haplotype of the holotype of Bathypathes ptiloides (USNM 1070974). The holotype of Bathypathes tiburonae (USNM 1116837), however, was not included in the DNA analysis.

Comparisons. Bathypathes tiburonae n. sp. differs from B. platycaulus by its subopposite pinnules, and from $B$. bifida by having more than one pair of pinnules. By its moderately tall pinnular spines (up to $0.09 \mathrm{~mm}$ ) $B$. tiburonae differs from $B$. erotema, B. patula, B. plenispina, B. ptiloides n. sp. and B. tenuis (all normally have spines $<0.06 \mathrm{~mm})$; and also $B$. bayeri $(0.1-0.32 \mathrm{~mm})$ and $B$. galathea $(0.08-0.2 \mathrm{~mm})$. It differs from $B$. conferta and the herein described $B$. alaskensis $\mathbf{n}$. sp. by less densely set pinnules (4-6 vs. 8-12 per $3 \mathrm{~cm}$ ) and larger polyps on the pinnules (9-12 $\mathrm{mm}$ vs. $4-5 \mathrm{~mm}$ in transverse diameter). 
Etymology. Species name "tiburonae" is derived from the name of MBARI's ROV Tiburon which was used to collect the holotype.

Distribution. Northeast Pacific, off California, Oregon and Alaska at depths of 3132-3356 m.

\section{Bathypathes alaskensis n. sp.}

(Fig. 5)

urn:Isid:zoobank.org:act:FB78EB75-A0DF-49B8-97CE-B7BE8B59327D

Bathypathus patula, MacIsaac et al. 2013: 240, 241, 251, 253, fig. 9; Brugler et al. 2013: 325, 327, 337, 343, fig. 2, fig. 3, fig. 4; Stone \& Shotwell 2007: 105

non Bathypathes patula Brook, 1889.

Material examined. Holotype: USNM 1288464 (SEM stub 419), off Kruzof Island, eastern Gulf of Alaska, 57.2167 N, 136.3490 ${ }^{\circ} \mathrm{W}$, ABL Longline Survey, 41-101B-1 (AB13-0029), coll. J.F. Karinen, 846 m, 18 July 2004 (specimen dry). Paratypes: USNM 1288463, E. of Yakutat Valley, eastern Gulf of Alaska, $58.8217^{\circ} \mathrm{N}, 141.0190^{\circ} \mathrm{W}$, ABL Longline Survey, 41-1A (AB13-0028), coll. J.F. Karinen, 731 m, 25 July 2004 (specimen dry); USNM 1288465, off Yakutat Valley, eastern Gulf of Alaska, $59.0483^{\circ} \mathrm{N}, 141.5690^{\circ} \mathrm{W}$, ABL Longline Survey, 41-95B (AB13-0030), coll. J.F. Karinen, 719 m, 30 July (specimen dry); USNM 1288466, off Cross Sound, eastern Gulf of Alaska, $57.6175^{\circ} \mathrm{N}, 136.6090^{\circ} \mathrm{W}$, ABL Longline Survey, 41-100-A1 (AB13-0032), coll. J.F. Karinen, $803 \mathrm{~m}$, 19 July 2004 (specimen dry); USNM 1288467, off Cross Sound, eastern Gulf of Alaska, $57.8817^{\circ} \mathrm{N}, 137.4420^{\circ} \mathrm{W}$, ABL Longline Survey, 41-99-2 (AB13-0033), coll. J.F. Karinen, 736 m, 21 July (specimen dry). Other material: USNM 99489, North Pacific, Alaska, Alexander Archipelago, R/V Albatross, sta. 4225, 272-331 m, 6 Jul 1903; USNM 100859, North Pacific, off Washington, $48.125^{\circ} \mathrm{N}, 125.846^{\circ} \mathrm{W}$, R/V Miller Freeman, sta. 4805F, West Coast Slope Fisheries Survey 2000, depth not recorded, 12 Oct. 2000; USNM 1013564, off Kruzof Island, eastern Gulf of Alaska, $57.1883^{\circ} \mathrm{N}, 136.2350^{\circ} \mathrm{W}$, ABL Longline Survey, R/V Alaskan Leader, No sta. no. (AB02-54), 700-715 m, 18 July 2002; USNM 1013566, off Kruzof Island, eastern Gulf of Alaska, $57.1883^{\circ} \mathrm{N}, 136.2350^{\circ} \mathrm{W}$, ABL Longline Survey, R/V Alaskan Leader, No sta.no. (AB02-53), 601-715 m, 18 July 2002 (2 specimens); USNM 1013568, SE of Yakutat Valley, eastern Gulf of Alaska, $58.6867^{\circ} \mathrm{N}, 140.7730^{\circ} \mathrm{W}$, ABL Longline Survey, R/V Alaskan Leader, No sta. no. (AB02-44), 565-567 m, 5 Aug 2002 (3 specimens). USNM 1013724, Dixon Entrance, eastern Gulf of Alaska, $54.9000^{\circ} \mathrm{N}, 134.2870^{\circ} \mathrm{W}, \mathrm{R} / \mathrm{V}$ Alaskan Leader, No sta. no. (AB02-61), 225-518 m, 11 July 2002 (3 specimens); USNM 1013749, Sitka Sound, eastern Gulf of Alaska, $56.8517^{\circ} \mathrm{N}, 135.9970^{\circ} \mathrm{W}, \mathrm{R} / \mathrm{V}$ Alaskan Leader, sta. 102 (AB02-55), 241-704 m, 17 July 2002; USNM 1014184, Canada, British Columbia, Queen Charlotte Islands, Graham Island, $54.0838^{\circ} \mathrm{N}, 134.1190^{\circ} \mathrm{W}$, Tow 6, coll. J. Boutillier, 1722-2083 m, 2 Sept 2002; USNM 1249987, eastern Gulf of Alaska, W of Prince of Wales Island, $54.9858^{\circ} \mathrm{N}, 134.3958^{\circ} \mathrm{W}$, ABL Longline Survey, 107B2 (AB130109), coll. J.F. Karinen, 637 m, 11 July 2006; USNM 1288461, Fairweather Ground, Gulf of Alaska, 58.2000 N, 138.9800W, ROV Zeuss II, GOA-15-157 (AB15-0013), coll. R.G. Stone, 515 m, 6 June 2015; USNM 1288462, Fairweather Ground, Gulf of Alaska, $58.2000^{\circ} \mathrm{N}, 138.9800^{\circ} \mathrm{W}$, ROV Zeuss II, GOA 15-158 (AB15-0014), coll. R.G. Stone, $515 \mathrm{~m}, 6$ June 2015; IORAS CNI00018, Gulf of Alaska, off Baranof Island, $56.7508^{\circ} \mathrm{N} 136.0330^{\circ} \mathrm{W}, \mathrm{R} / \mathrm{V}$ Vityaz cruise 45, sta. 6122, Sigsbee Trawl, 1100-1180 m, 21 May 1969.

Diagnosis. Moderately sized (up to $40 \mathrm{~cm}$ or more in height), monopodial (unbranched) pinnulate colonies. Simple flexible pinnules arranged in two anterolateral to lateral rows and in subopposite pairs. Unpinnulated lower section of stem typically 6.5 to $10 \mathrm{~cm}$ in length; pinnulated section of stem up to $34 \mathrm{~cm}$ long on colony $43 \mathrm{~cm}$ tall, with pinnules up to $23 \mathrm{~cm}$ in length. Striatum usually present on polypar side of stem starting several centimeters above basal plate and extending for 2-4 cm, and ending at slight curvature in stem; often with spines along ridges separated by shallow grooves. Pinnular density $8-12$ per $3 \mathrm{~cm}(12-16$ per $5 \mathrm{~cm})$. Spines smooth, simple, conical, with rounded apex or apically forked leading to the formation of double and triple spines. Largest polypar spines on pinnules mostly $0.11-0.14 \mathrm{~mm}$ tall; abpolypar spines $0.08-0.09 \mathrm{~mm}$ tall. Spines on stem similar to those on pinnules except along the striatum where they can be as tall as $0.18 \mathrm{~mm}$. Polyps uniserially arranged; mostly 4 to $5 \mathrm{~mm}$ in transverse diameter (range 3-6 mm); polyp density usually 4-5 per two centimeters. Color of living colonies light to dark orange. 

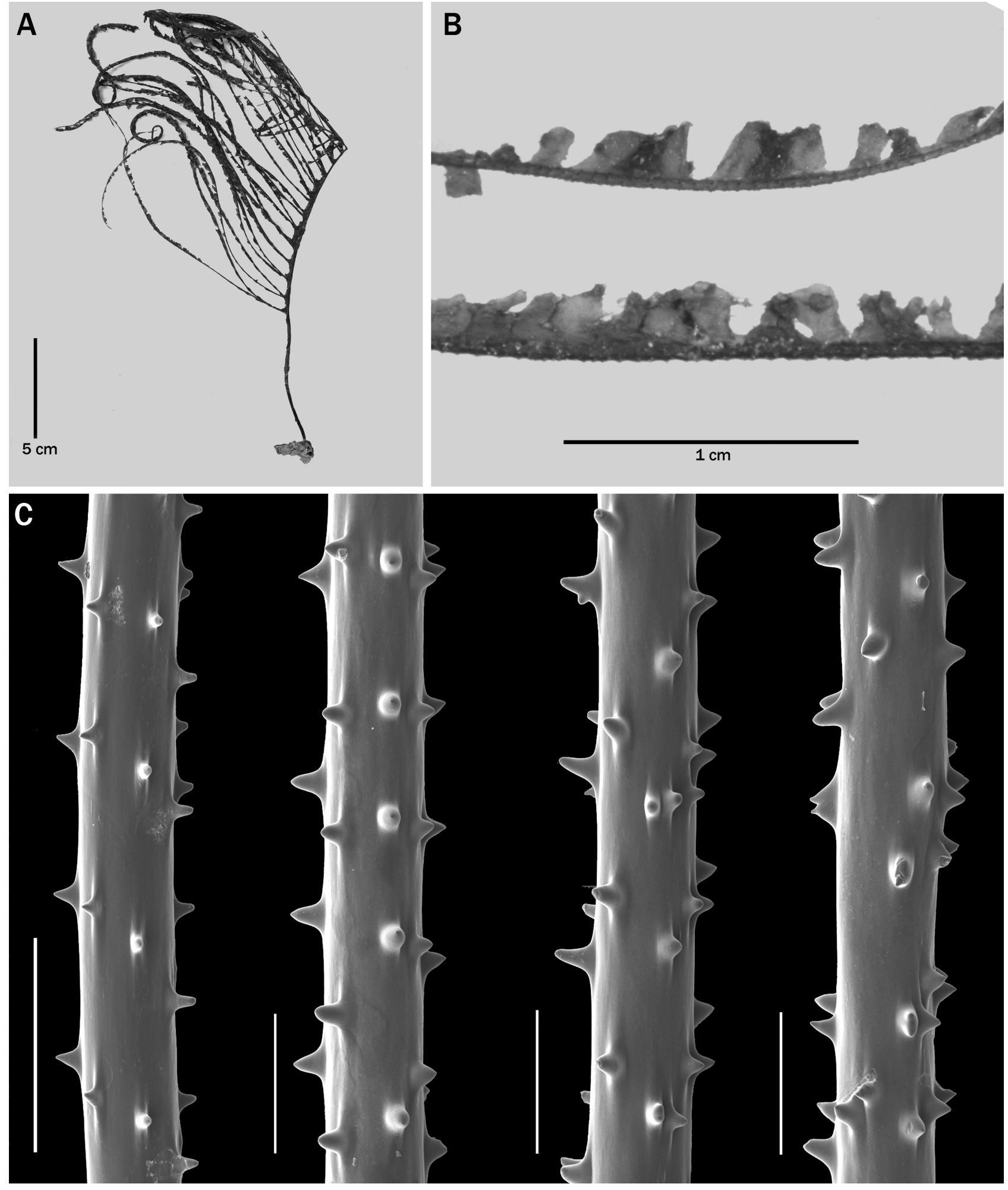

FIGURE 5. Bathypathes alaskensis n. sp., holotype, USNM 1288464: A. corallum; B. polyps; C. sections of pinnules showing spines, scale bars $0.5 \mathrm{~mm}$ (C from SEM stub 419).

Description of holotype. The holotype (USNM 1288464, Fig. 5A) is about $26 \mathrm{~cm}$ tall; the unpinnulated portion of the stem is $7 \mathrm{~cm}$ long, and its diameter just above the basal plate is $1.9 \mathrm{~mm}$. This section shows a very slight S-shaped curvature; first tilted towards the front or polypar side of the corallum, then curving towards the abpolypar side, and finally extending almost vertically. A striatum (low axial ridges separated by shallow grooves), confined to one side of the axis, appears about $3 \mathrm{~cm}$ above the basal plate and extends for about $2 \mathrm{~cm}$, and has large spines along the crest of some of the ridges. The pinnulated portion of the corallum is $19.5 \mathrm{~cm}$ in length and curves back 
away from the polypar side of the axis (Note: in Fig. 5A the distal-most $4 \mathrm{~cm}$ of the stem is broken and folded over the lower section). The pinnules are arranged bilaterally and also in subopposite pairs, the left pinnule of each pair (viewing the polyp-side of the corallum) is inserted on the axis slightly lower than the opposite member. The pinnules are relatively long compared to the height of the corallum; the longest ( $6^{\text {th }}$ pair from the bottom) being about $19 \mathrm{~cm}$, with a basal diameter of about $0.6 \mathrm{~mm}$. The pinnules are mostly 7-9 $\mathrm{mm}$ apart within each row; with a total for both rows of up to 8 per $3 \mathrm{~cm}(\sim 12$ per $5 \mathrm{~cm})$ on the lower part of the stem and up to 10 per $3 \mathrm{~cm}(14$ per $5 \mathrm{~cm})$ about $13 \mathrm{~cm}$ above the base and approximately 12 per $3 \mathrm{~cm}$ (nearly 16 per $5 \mathrm{~cm}$ ) on the upper part of the stem. In the preserved specimen, the interior angle formed by the two rows of pinnules is about $45^{\circ}$ on the lower part of the stem, but it may have been even smaller in the living colony. The pinnules on the upper part of the corallum are more spread apart forming an interior angle of up to $160^{\circ}$ near the top of the stem. The distal angle formed by the pinnules and the stem is generally near $60^{\circ}$. The pinnular spines (Fig. 5C) are smooth, conical, with a rounded apex or apically forked. On segments of pinnules about $0.33 \mathrm{~mm}$ in diameter, the polypar spines are mostly $0.11-0.13$ $\mathrm{mm}$ tall, the abpolypar spines $0.07-0.08 \mathrm{~mm}$ tall. The spines are arranged in axial rows, 5-7 of which can be seen in lateral view (including only rows in which the base of the spines is visible). Within each row there are 2.5-3.5 spines per $\mathrm{mm}$. Spines on the stem are similar to those on pinnules except along the striatum where they can be as tall as $0.18 \mathrm{~mm}$. Also, in one small area on the stem the polypar spines are up to $0.23 \mathrm{~mm}$ and very wide and blunt - perhaps an abnormal condition. The polyps (Fig. 5B) are arranged uniserially on the stem and pinnules. On the pinnules they most often occur on the lower side of the axis - facing down or away from the corallum; however, on a few pinnules they occur on the upper surface. On the same pinnule, polyps may occur on either side, but not in the same location. The polyps are mostly 4 to $5 \mathrm{~mm}$ in transverse diameter (measured from the distal edge of the distal lateral tentacles to the proximal edge of the proximal lateral tentacles); the interpolypar space is about $1 \mathrm{~mm}$ wide or less and there are 4 to 5 polyps per $2 \mathrm{~cm}$.

Description of paratypes and other material. The five specimens in the type series (USNM 1288463, 1288464, 1288465,1288466 , and 128467) allow for an evaluation of the morphological variability of the species. Polyp size (transverse diameter) ranges from 4 to $6 \mathrm{~mm}$ and polyp density from 3 to about 5 per two centimeters (in many of the colonies the polyps appear enlarged and very crowded due to their being filled with reproductive cells). Pinnular density ranges from 8 to 12 (total for both rows) per three centimeters of stem, and varies both within and between colonies, often with the pinnules becoming more crowded higher on the corallum. The lower unpinnulated section of the stem varies in length from 6.5 to $9 \mathrm{~cm}$ between colonies. The interior angle between the two rows of pinnules ranges from about $30^{\circ}$ to close to $180^{\circ}$; and the distal angle can be as little as $45^{\circ}$ to as much as $90^{\circ}$. These five specimens also show that the curvature of the stem changes with size of the corallum. Usually the smaller colonies are relatively upright or only slightly curved away from the polypar side of the corallum; larger colonies, however, tend to be extremely curved away from the polypar side. The length of the longest pinnules is 9 to $14 \mathrm{~cm}$ in colonies 15 to $20 \mathrm{~cm}$ tall, but as much as $23 \mathrm{~cm}$ in a colony $43 \mathrm{~cm}$ tall. In preserved specimens the interior angle between the two rows of pinnules can range from less than $30^{\circ}$ to more than $160^{\circ}$ within the same colony, but without detailed in situ photographs it cannot be determined to what degree this feature is normal or only an artifact of the method of preservation.

The examination of five additional specimens assigned to this species supports the conclusions reached above. The colonies exhibit varying morphologies from upright, to slightly curved, to extremely curved, but none are sigmoidal or sickle-shaped, although in many specimens the middle to upper part of the unpinnulated portion of the stem exhibits a slight S-shaped curvature. Overall, the longest pinnules are usually not more than about $20 \mathrm{~cm}$ in colonies as much as $40 \mathrm{~cm}$ tall (except in cases where the top of the colony might have been broken off), the maximum pinnular density is 12 pinnules per $3 \mathrm{~cm}$, the pinnular spines are rarely more than $0.14 \mathrm{~mm}$ tall, and the polyps are usually $4-5 \mathrm{~mm}$ in transverse diameter, with $4-5$ polyps per $2 \mathrm{~cm}$.

Genetic data. GenBank Acc. Nos.: USNM 1288464 [JX560735 (igrW), JX560746 (igrN), JX560756 (cox3-cox1)]; USNM 1288463 [KF054475 (igrW), KF054608 (igr N), KF054368 (cox3-cox1)]; USNM 1288465 [KF054477 (igrW), KF054609 (igrN), KF054369 (cox3-coxl)]; USNM 1288466 [KF054476 (igrW), KF054610 $(i g r N)$ ]; USNM 1288467 [KF054478 (igrW), KF054611 (igrN), KF054370 (cox3-coxl)].

The five specimens in the type series were sequenced by Brugler et al. (2013) using three markers (igrW, igrN, and $\operatorname{cox} 3-\operatorname{cox} 1$ ), and the sequences were deposited in GenBank under the name Bathypathes patula. With the exception of one unresolved marker for one specimen ( $\operatorname{cox} 3-\operatorname{cox} 1$ for USNM 1288466), the results indicated that all five belong to the same species. It is rare to have multiple specimens in a type series subjected to DNA analysis. For 
antipatharians which in general exhibit a high degree of morphological plasticity as discussed above for this species, this is extremely valuable in making it possible to define species limits in terms of each major taxonomic character. Ideally this information can be coupled with additional morphological and genetic data on specimens from the same and other geographic regions to more fully document species ranges and to recognize cryptic species.

Comparisons. This species differs from B. platycaulus by its subopposite pinnules and from B. bifida by having more than one pair of pinnules. In $B$. alaskensis $\mathbf{n}$. sp. the largest polypar spines on the pinnules $(0.1-0.14 \mathrm{~mm})$ are, in most colonies, larger than those in B. conferta, B. erotema, B. patula, B. plenispina, B. ptiloides and B. tenuis (all normally have polypar spines $<0.08 \mathrm{~mm}$ ) and about one-half the size of those in $B$. bayeri $(0.2-0.32 \mathrm{~mm})$ and $B$. galatheae ( 0.18 to $0.26 \mathrm{~mm}$ ). The spines in B. patula, B. plenispina, B. erotema, and B. conferta are more triangular with an acute apex compared to the conical spines with a rounded apex in B. alaskensis. Bathypathes alaskensis $\mathbf{n}$. sp. differs from $B$. tiburonae $\mathbf{n}$. sp. by its more densely set pinnules (8-12 vs. 4-6 per $3 \mathrm{~cm}$ ) and smaller polyps (4-5 $\mathrm{mm}$ vs. $9-12 \mathrm{~mm}$ in transverse diameter).

In in situ photos, this species can also be differentiated from B. patula by its orange color and more flexible pinnules (color of B. patula is white), and also by the absolute and relative length of the pinnules on colonies of comparable size. In colonies about $20 \mathrm{~cm}$ in height, the longest pinnules in the type of $B$. patula are $7.5 \mathrm{~cm}$, whereas those in B. alaskensis are $14.5 \mathrm{~cm}$. The relative length of the pinnules in B. alaskensis is similar to that in $B$. galathea (maximum of $14.2 \mathrm{~cm}$ in a colony with a pinnulated section $26.5 \mathrm{~cm}$ long); however, the pinnules in $B$. galatheae are straighter, more robust and not flexible, and the distal angle wider, close to $90^{\circ}$.

Etymology. Species name "alaskensis" is derived from the general region where the species is found, the Gulf of Alaska.

Distribution. All of the specimens assigned to this species were collected in the Northeast Pacific, primarily from the Gulf of Alaska, and nearby seamounts at depths between 272 and $1200 \mathrm{~m}$.

\section{Parantipathes Brook, 1889}

partim Parantipathes Brook, 1889: 141; van Pesch 1914: 96.

Parantipathes, Opresko 2002: 435-437; Pasternak 1977: 160-161; Molodtsova \& Pasternak 2005: 170; Molodtsova 2006: 142; Brugler et al. 2013: 318; Bo et. al. 2014: 115; Opresko 2015: 157.

partim Bathypathes, Pasternak 1958: 187.

not Bathypathes Brook, 1889: 151.

Diagnosis. Corallum monopodial to sparsely branched, stem and branches pinnulate. Pinnules simple, arranged in at least six axial rows, and in alternating semispiral groups of three or more on either side of the axis. Spines usually simple (rarely with apical lobes), triangular or conical, acute, and often laterally compressed. Polyps mostly 1.6 to about $3 \mathrm{~mm}$ in transverse diameter.

Type species. Antipathes larix Esper, 1790

Remarks. The genus Parantipathes is very close morphologically to Lillipathes in that species in both genera have simple pinnules arranged bilaterally in axial rows, and also in alternating groups in which the members of the group are slightly offset such that they follow a semispiral pattern. The main difference between the two genera is that in Parantipathes there are typically three or more pinnules per group, which is equivalent to three or more axial rows on each side of the stem and branches (when present); whereas in Lillipathes there are no more than two pinnules per group, equivalent to a maximum of four rows of pinnules (two on each side). However, in species of Parantipathes there are only four rows of pinnules on the lower parts of the corallum, increasing to six or more rows (groups of three or more) on the upper parts. This means that if a juvenile colony or if only a developing branch of a colony is collected that has only four rows of pinnules, it could easily be misidentified as Lillipathes. Currently there is no other taxonomic character that clearly separates these two genera. In DNA sequencing studies using the mt gene regions nad5-nadl and cox3-coxl the two genera were not separable (Brugler et al. 2013); however, additional mitochondrial and nuclear markers need to be evaluated.

Species assigned to the genus. Parantipathes dodecasticha Opresko, 2015, Bathypathes euantha Pasternak, 1958, Parantipathes helicosticha Opresko, 1999, Parantipathes hirondelle Molodtsova, 2006, Parantipathes laricides van Pesch, 1914, Antipathes larix Esper, 1790, Parantipathes robusta Opresko, 2015; Antipathes tetrasticha Pourtalès, 1868, Parantipathes wolffi Pasternak, 1977, and Parantipathes pluma n. sp. 
Distribution. The genus has been found in the Atlantic, Pacific and Indian Ocean at depths of 120-1872 m; however, recent genetic studies conducted on samples from both the Pacific and Atlantic indicate that, based on $\mathrm{mt}$ cox3-coxl and nad5-nad, the species in the two ocean basins fall into two separate clades (Chery et al. 2018).

\section{Parantipathes pluma n. sp.}

(Figs 6-8)

urn:lsid:zoobank.org:act:7E0195DB-65A4-4DD9-9320-C013B125012A

Parantipathes sp. Brugler et al. 2013: fig. 7A, 7D.

Material examined. Holotype: USNM 1093058 (SEM stub 503), N. Pacific, central Aleutian Islands, S. of Amlia Island, ROV Jason II, Dive 95 (Field Identification Number: J2095-2-7-4), 51.8116N, 173.8328 W, $843 \mathrm{~m}$, coll. R. Stone, 25 July 2004 (specimen dry). Paratype: USNM 1498742 (SEM stub 510), N. Pacific, Bering Sea, Zhemchug Canyon, F/V Cape Flattery, $58.5395^{\circ} \mathrm{N}, 175.0640^{\circ} \mathrm{W}, 977 \mathrm{~m}$, coll. J. Hoff, $10 \mathrm{Jul}$ 2016. Other Material: USNM 1093061, N. Pacific, central Aleutian Islands, Bobrof Island Pass, ROV Jason II, Dive 106 (Field Identification Number: J2106-7-1), 51.8924 N, $177.2863^{\circ} \mathrm{W}, 936$ m, coll. R. Stone, 7 Aug 2004; USNM 1482130, N. Pacific, central Aleutian Islands, SW of Adak Island, F/V Ocean Olympic, $51.5270^{\circ} \mathrm{N}, 177.0170^{\circ} \mathrm{W}, 329 \mathrm{~m}$, coll. G. Nightengale, Oct 2004.

Diagnosis. Tall colonies, monopodial, unbranched or sparsely branched to the second order. Stem and branches pinnulate. Pinnules mostly simple, up to $13 \mathrm{~cm}$ long, arranged bilaterally along the stem, and, in varying degrees of regularity within and between colonies, with two to three rows on each side of axis, and in alternating semispiral groups typically consisting of two or three, and very rarely four pinnules. Pinnular density very variable depending on specimen, location on corallum, number of pinnules per group, and spacing of pinnules within and between groups; commonly 13-16 total per $\mathrm{cm}$, but ranging from about 10 to 19 per $\mathrm{cm}$. Pinnular spines usually simple (rarely with apical lobes), smooth, perpendicular to the axis, with 4-5 spines per mm; polypar spines mostly $0.06-0.08$ $\mathrm{mm}$ tall (maximum about $0.09 \mathrm{~mm}$ ); abpolypar spines $0.04-0.06 \mathrm{~mm}$. Polyps on pinnules estimated to be $2.8-3.2$ $\mathrm{mm}$ in transverse diameter with $2.5-3$ polyps per $\mathrm{cm}$.

Description of holotype. Holotype (USNM 1093058, Fig. 6A) monopodial, without branches, but pinnulate with simple pinnules in multiple rows along the axis. Holdfast and lower unpinnulated section of stem missing; stumps of pinnules present to bottom of remaining part of stem. Apical section of corallum retained. Remaining section of stem $104 \mathrm{~cm}$ long (in three broken pieces). Stem diameter $5.7 \mathrm{~mm}$ at broken off basal end. Pinnules (Fig 6B) simple, elongate, arranged bilaterally with two or three rows on each side of the axis, and also in groups of two or three pinnules, one from each row. Spacing of pinnules within each group very irregular both along the axis and around it; therefore, the groups of pinnules are often not in clearly defined semispirals. Pinnules within a group mostly 1-2 mm apart, and a clearly defined semispiral group of three pinnules covers an axial distance of about $3.5 \mathrm{~mm}$. Pinnules are 11-13 cm long and $0.4-0.6 \mathrm{~mm}$ in diameter near the base, and inclined distally (distal angle $\left.40-60^{\circ}\right)$. Pinnules subequal in length in all rows. Pinnular density very variable, but commonly $11-13$ total per $\mathrm{cm}$ (range 9-16 per $\mathrm{cm}$ ). Pinnules in only 4 rows at bottom of stem, with 10 pinnules total per $\mathrm{cm}$. Pinnular spines (Fig. 7) are smooth, triangular in lateral view, mostly standing nearly perpendicular to the axis, but with some inclined distally and a few inclined basally (relative to the direction of the pinnule). The apex can be acute or rounded. On sections of pinnules where the axis is $0.31-0.37 \mathrm{~mm}$ in diameter (excluding spines), the polypar spines are typically $0.07-0.08 \mathrm{~mm}$ tall (maximum about $0.09 \mathrm{~mm}$ ), and the abpolypar spines are usually $0.04-0.06 \mathrm{~mm}$ tall (maximum about $0.07 \mathrm{~mm}$ ). On sections of pinnules where the axis is $0.20-0.23 \mathrm{~mm}$ in diameter (excluding spines) and the spines are more compressed laterally, the polypar spines are mostly $0.06 \mathrm{~mm}$ tall and the abpolypar spines are only slightly smaller. The spines are arranged in axial rows, six or seven of which can be seen in lateral view, and within the rows there are 4-5 spines per mm. On some sections of the pinnules the rows of polypar spines often appear very crowded together when compared to the rows of abpolypar spines. Often the base of the spines extends out along the axis distally and basally forming axial ridges. The polyps are in a very poor state of preservation (colony dry). They are uniserially arranged on the pinnules, often on the upper or lower side such that those on adjacent pinnules on the same side of the corallum tend to face towards each other. The transverse diameter of the polyps is estimated to range from 2.8 to $3.2 \mathrm{~mm}$, but is mostly close to $3 \mathrm{~mm}$, with 2.5 to 3 polyps per centimeter. 

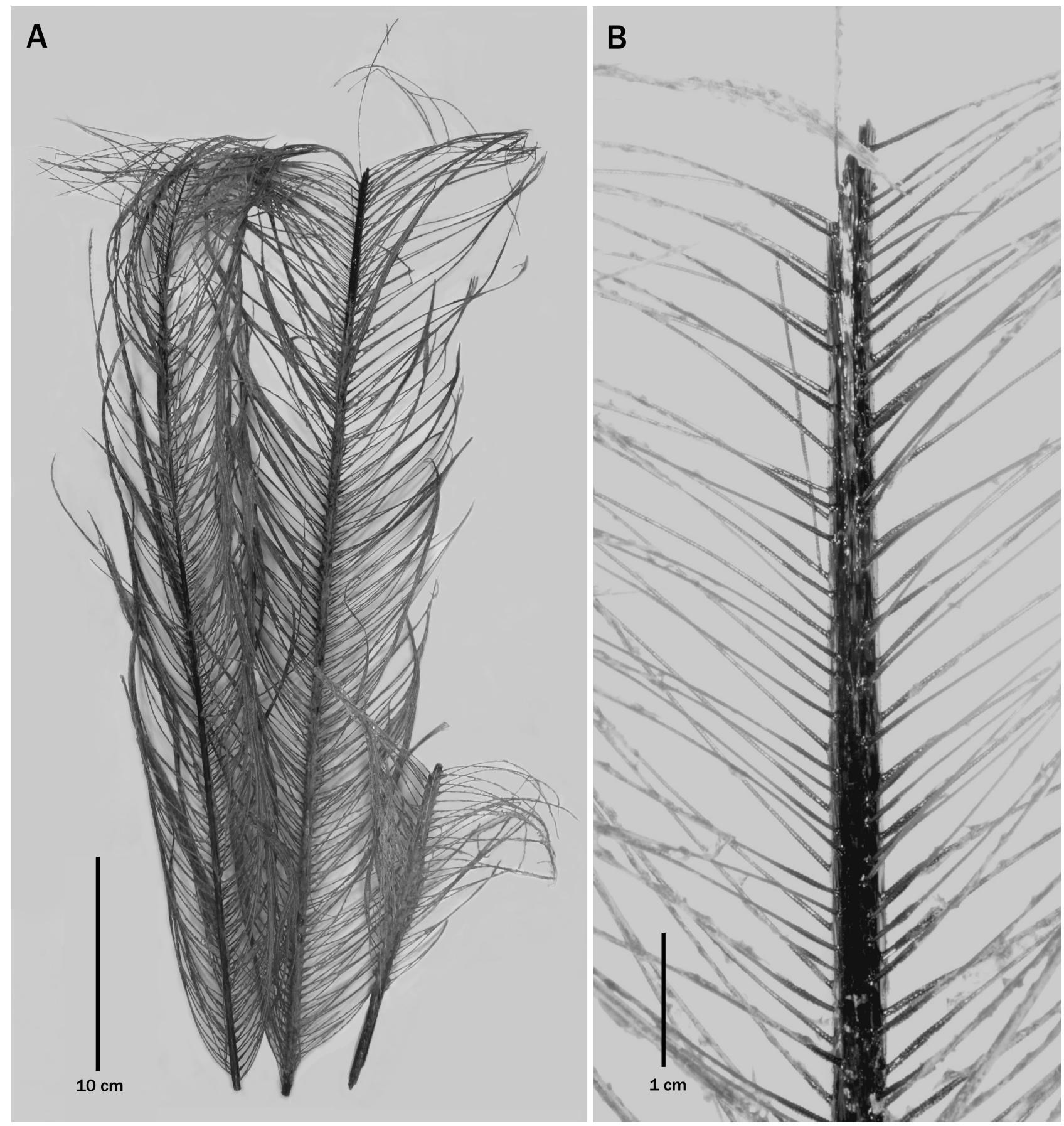

FIGURE 6. Parantipathes pluma n. sp., holotype, USNM 1093058: A. corallum; B. close-up view of middle section of corallum showing arrangement of pinnules.

Description of paratypes and other material. The specimen selected as a paratype of Parantipathes pluma (USNM 1498742) is an almost complete monopodial colony, without branches, but is only half the size of the holotype (Fig. 8A). The stem is $55 \mathrm{~cm}$ long (in four broken pieces) and has a basal diameter of 3 by $3.4 \mathrm{~mm}$ just above the holdfast. Pinnulation begins about $2.5 \mathrm{~cm}$ above the holdfast. As in the holotype, the pinnules are arranged bilaterally, with three rows on each side of the stem, and they are subequal in length in all rows. The longest pinnules are 11 $\mathrm{cm}$ long and have a basal diameter of about $0.4 \mathrm{~mm}$. Pinnules (Fig. 8C) are mostly in alternating semispiral groups of three on each side of the axis (very rarely four per group). The pinnular density along most of the stem is about five groups of three pinnules per $\mathrm{cm}$, but because of varying interpinnular distances and the overlap of pinnules on each side of the axis, the total number of pinnules per $\mathrm{cm}$ ranges from 14 to 19 per $\mathrm{cm}$, compared to a typical 

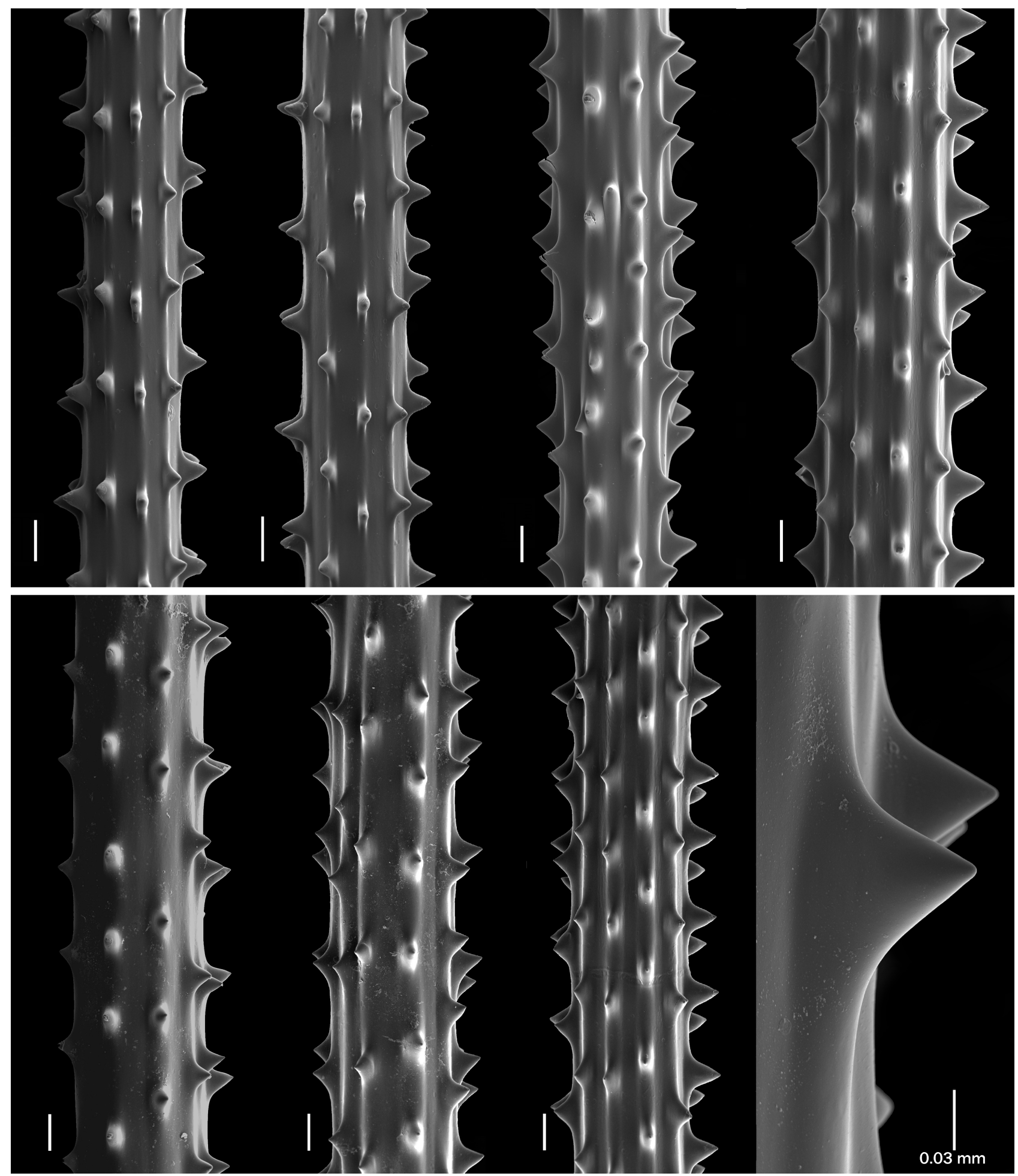

FIGURE 7. Parantipathes pluma n. sp., holotype, USNM 1093058, sections of pinnules. Scale bars 0.1 mm except as indicated.

range of 11-13 per $\mathrm{cm}$ in the holotype. The semispiral groups of three pinnules cover a distance of 2 to $2.5 \mathrm{~mm}$. The pinnules on lowest part of stem are in groups of two. In places along the stem the pinnular arrangement in rows and semispiral groups becomes very distorted as in the holotype. The pinnules in all rows are inclined distally such that the distal angle they form with the stem is close to $45^{\circ}$, but nearer the top of the stem this increases to about $60^{\circ}$. The interior angle formed between the two posterior rows of pinnules is about $180^{\circ}$; that of lateral and anterior rows is around $120^{\circ}$. The pinnular spines (Fig. $8 \mathrm{~B}$ ) are similar to those in the holotype in being triangular in lateral view, standing nearly perpendicular to the axis. They have an acute to rounded apex. On sections of pinnules 0.2 to 0.32 $\mathrm{mm}$ in diameter, the polypar spines are 0.07 to $0.086 \mathrm{~mm}$ tall, and slightly larger than the abpolypar spines ( 0.04 to 
$0.07 \mathrm{~mm}$ ). Four or five rows of spines are visible in lateral view, and there are 4-5 spines per mm in each row. On the lower part of some pinnules (5-10 mm above base) the sclerenchyme becomes thickened and the spines on one side of the axis have multiple (usually 2-4) conically-shaped, apical lobes (Fig. 8D). On the lower part of the stem, the spines are up to about $0.09 \mathrm{~mm}$ tall and appear to be in clusters, although these spines may have originated as single spines with multiple apical lobes as those on the lower sections of some of the pinnules. Polyps are too poorly preserved to estimate their size or density.

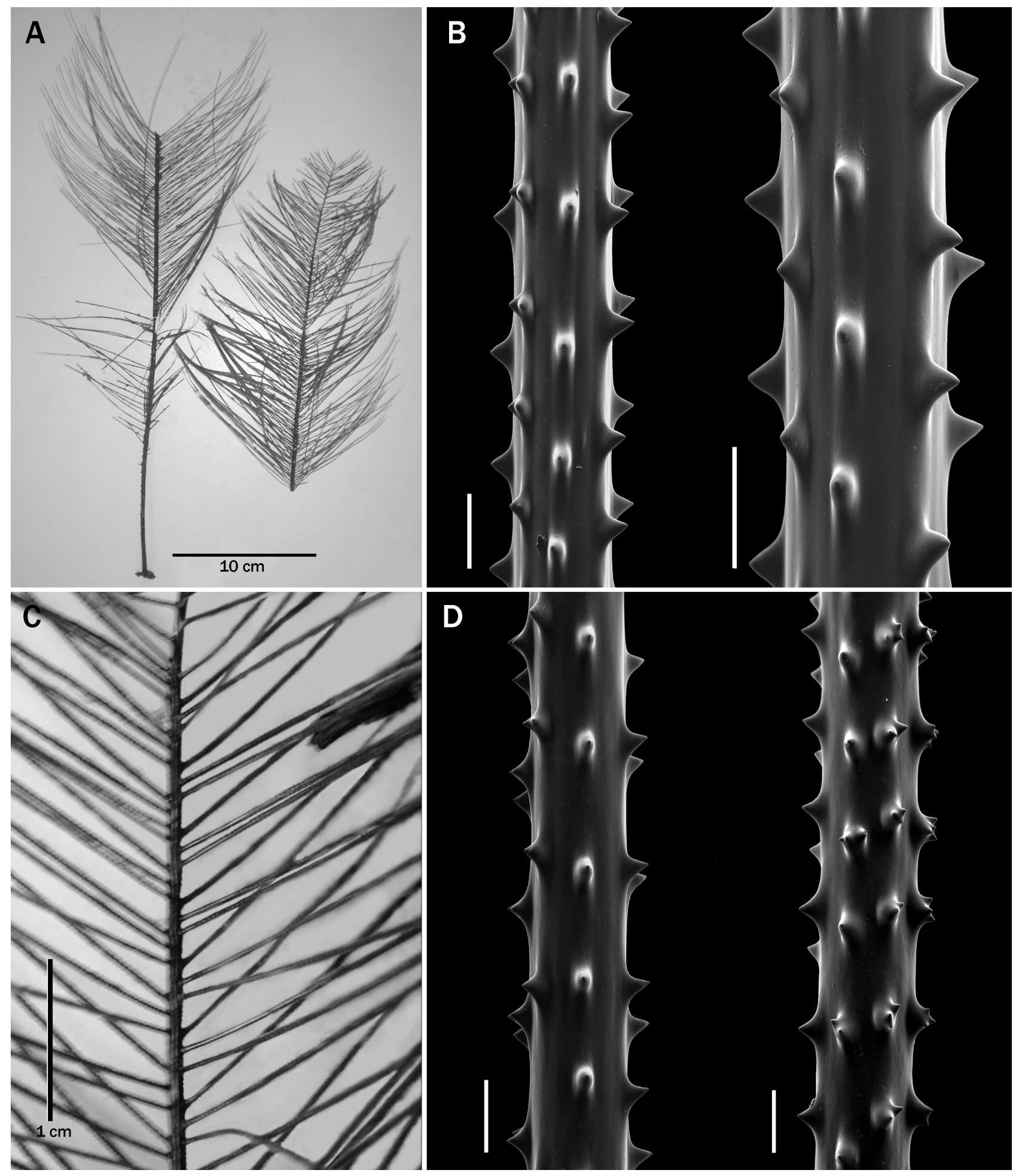

FIGURE 8. Parantipathes pluma n. sp., paratype, USNM 1498742: A. corallum; B. middle sections of pinnules, scale bars 0.2 $\mathrm{mm}$; C. close-up view of middle section of corallum showing arrangement of pinnules; $\mathbf{D}$. basal sections of pinnules, scale bars $0.2 \mathrm{~mm}$. (B and D from SEM stub 510). 
The other two specimens assigned to this species (USNM 1093061 and USNM 1482130) are similar to the type in having pinnules up to $13 \mathrm{~cm}$; pinnules in semispiral groups of mainly two or three; and with spines $0.05-0.07 \mathrm{~mm}$ tall. In situ photos of USNM 1093061 (Brugler et al. 2013: 7A) indicate that the colony was very sparsely branched to the second order; however, only a single branch was collected.

Genetic data. GenBank Acc. Nos.: USNM 1093058, holotype [KF054491 (igrW), KF054637 (igrN), and KF054384 (cox3-coxl)]; USNM 1093061 [KF054490 (igrW), KF054644 (igrN), and KF054384 (cox3-cox1)].

DNA sequencing studies using the $\mathrm{mt}$ gene regions listed above (Brugler et al. 2013), as well as those using nad5-nad1 (Chery et al. 2018), revealed that all haplotypes of the holotype of P. pluma (USNM 1093058) were identical to those of other Pacific Parantipathes specimens, and to Pacific specimens of Lillipathes and Dendrobathypathes Opresko, 2002. Atlantic species of Parantipathes, including P. larix (Esper, 1790), however, fell into a separate subclade. These results suggest either a polyphyletic origin of the Parantipathes morphotype, or a relatively high degree of genetic change and possibly interchange following the isolation of the populations in separate oceanic basins.

Comparisons. Parantipathes pluma n. sp. differs from most of the hitherto known species of the genus by its very long pinnules which are typically more than $10 \mathrm{~cm}$ long. The new species is superficially similar to the Atlantic species Parantipathes larix in the maximum length of the pinnules (11-13 cm vs. $6-13 \mathrm{~cm}$ in P. larix), number of rows of pinnules (4-6), and in the size of the polypar spines on the pinnules (up to $0.09 \mathrm{~mm}$ vs. up to $0.11 \mathrm{~mm}$ in $P$. larix), but differs in the larger size of the polyps $(2.8-3.2 \mathrm{~mm}$ vs. $1.6-2.2 \mathrm{~mm})$ and in the lower density of the pinnules (mostly $11-13$ per cm vs. 21 per cm). In addition, the distal angle of the pinnules is $80-90^{\circ}$ in $P$. larix and much less in $P$. pluma, $\left(40-60^{\circ}\right)$, the number of rows of spines seen in lateral view is greater (6-7 vs. 3-4), and the spines can be distinctly curved distally in $P$. larix but are more at right angles to the axis in P. pluma. As noted above, P. pluma is genetically distinct from P. larix. The one other species of Parantipathes found in the northern Pacific, $P$. euantha (see Molodtsova \& Pasternak 2005 for redescription), which was described from a relatively small colony, differs from Parantipathes pluma in having shorter pinnules (up to $3.8 \mathrm{~cm}$ ) and smaller polyps $(1.9-2.7 \mathrm{~mm}$ ). The type specimen of $P$. euantha was preserved in Bouin fixative, so it is not available for genetic studies.

Etymology. Species name "pluma" is derived from the Latin "pluma", meaning "feather", in reference to the general shape of the corallum.

Distribution. Known only from the North Pacific at depths ranging from 329 to $977 \mathrm{~m}$.

\section{Acknowledgements and Funding}

The authors wish to thank the funding agencies, and the participants in the research voyages during which the described specimens were collected. Special thanks go to R. Stone, J.F. Karinen, and J. Hoff of NOAA, J. Boutillier of Fisheries and Oceans Canada, A. Baco-Taylor of Florida State University, and L. Lundsten of MBARI for providing specimens described in this report. The authors also wish to thank S. Cairns, W. Keel, W. Moser, and K. Reed for their assistance during visits to the NMNH, A. Cabrinowic, N. Santodomingo and M. Lowe for their help and assistance during visits to the NHMUK (London), M. Daly for her editorial guidance, and two anonymous reviewers for their careful evaluation of the manuscript. The photomicrographs were prepared in the SEM Laboratory of the NMNH. D.M. Opresko is a Research Associate of the NMNH, and gratefully acknowledges that affiliation. Funding for this project was provided, in part, by a U.S. Department of Justice grant to the Smithsonian Institution. T. Molodtsova was funded by the Minobrnauki of the Russian Federation State, Assignment No. 0149-2019-0009 and Agreement No. 075-15-2020-796.

Disclosure statement. No potential conflict of interest was reported by the authors.

\section{References}

Barrett, N.J., Hogan, R., Allcock, L., Molodtsova, T.N., Hopkins, K.P., Wheeler, A.J. \& Yesson, C. (2020) Phylogenetics and mitogenome organisation in black corals (Anthozoa: Hexacorallia: Antipatharia): an order-wide survey inferred from complete mitochondrial genomes. Frontiers in Marine Science, 7 (440), 1-14. https://doi.org/10.3389/fmars.2020.00440

Bo, M., Canese, S. \& Bavestrello, G. (2014) Discovering Mediterranean black coral forests: Parantipathes larix (Anthozoa: 
Hexacorallia) in the Tuscan Archipelago. Italian Journal of Zoology, 81, 112-125.

https://doi.org/10.1080/11250003.2013.859750

Brook, G. (1889) Report on the Antipatharia. Report on the Scientific Results of the Voyage of the HMS Challenger during the years 1873-1876, Zoology, 32, 1-222.

Brugler, M.R., Opresko, D.M. \& France, S.C. (2013) The evolutionary history of the order Antipatharia (Cnidaria: Anthozoa: Hexacorallia) as inferred from mitochondrial and nuclear DNA: implications for black coral taxonomy and systematics. Zoological Journal of the Linnean Society, 169, 312-361. https://doi.org/10.1111/zoj.12060

Chery, N., Parra, K., Evankow, A., Stein, D., Distel, D., Appiah-Madson, H., Ross, R., Sanon, E., Alomari, N., Johnson, R., Vasovic, A., Horowitz, A., Popa, H., Short, B., Kourehjan, D., Vasquez, D.M., Rodriguez, E., Opresko, D.M. \& Brugler, M.R. (2018) Partnering with the Ocean Genome Legacy to advance our understanding of black corals (Order Antipatharia). $15^{\text {th }}$ Deep-Sea Biology Symposium, Monterey, California, 9-14 September 2018. poster presentation. [preprint available from M. Brugler at https://tidalmarshtaskforce.wixsite.com/uscb/publications]

Esper, E.J.C. (1790) Die Pflanzenthiere in Abbildungen nach der Natur mit Farben erleuchtet nebst Beschreibungen, Pflanzenthiere 1, Lieferung 5, Raspe, Nürnberg, pl. 4. [see also 1792, Pflanzenthiere 2, p. 147] https://doi.org/10.5962/bhl.title.118730

Gravier, C. (1918) Note preliminaire sur les Hexactiniaires recueillis au cours des croisieres de la Princesse-Alice et de l'Hirondelle de 1888 a 1913 inclusivement. Bulletin de l'Institut océanographique de Monaco, 346, 1-24.

Horowitz, J., Opresko, D.M. \& Bridge, T.C.L. (2018) Black corals (Anthozoa: Antipatharia) from the deep (916 m-2542 m) Coral Sea, north-eastern Australia. Zootaxa, 4472 (2), 307-326. https://doi.org/10.11646/zootaxa.4472.2.5

Horowitz, J., Brugler, M.R., Bridge, T.C.L. \& Cowman, P.F. (2020) Morphological and molecular description of a new genus and species of black coral (Cnidaria: Anthozoa: Hexacorallia: Antipatharia: Antipathidae: Blastopathes) from Papua New Guinea. Zootaxa, 4821 (3), 553-569. https://doi.org/10.11646/zootaxa.4821.3.7

MacIsaac, K.G., Best, M., Brugler, M.R., Kenchington, E.L.R., Anstey, L.J. \& Jordan, T. (2013) Telopathes magna gen. nov., spec. nov. (Cnidaria: Anthozoa: Antipatharia: Schizopathidae) from deep waters off Atlantic Canada and the first molecular phylogeny of the deep-sea family Schizopathidae. Zootaxa, 3700 (2), 237-258. https://doi.org/10.11646/zootaxa.3700.2.3

Milne Edwards, H. (1857) Histoire Naturelle des Coralliaires ou Polypes Proprement Dits. Roret, Paris, 360 pp.

Molodtsova, T.N. (2006) Black corals (Antipatharia: Anthozoa: Cnidaria) of North-East Atlantic. In: Mironov, A.N., Gebruk, A.V. \& Southward, A.J. (Eds.), Biogeography of the North Atlantic seamounts. KMK Press, Moscow, pp. 141-151.

Molodtsova, T.N. (2014) Deep-sea fauna of European seas: An annotated species check-list of benthic invertebrates living deeper than $2000 \mathrm{~m}$ in the seas bordering Europe. Antipatharia. Invertebrate Biology, 11 (1), 3-7. https://doi.org/10.15298/invertzool.11.1.02

Molodtsova, T.N. \& Opresko, D.M. (2017) Black corals (Anthozoa: Antipatharia) of the Clarion-Clipperton Fracture Zone. Marine Biodiversity, 47 (2), 349-365. https://doi.org/10.1007/s12526-017-0659-6

Molodtsova, T.N. \& Pasternak, F.A. (2005) Redescription of Parantipathes euantha (Pasternak, 1958) (Anthozoa: Antipatharia) from Kurile-Kamchatka Trench. Invertebrate Zoology, 2 (2), 169-179.

Opresko, D.M. (1999) New species of Antipathes and Parantipathes (Cnidaria: Anthozoa: Antipatharia) from coastal waters of South Australia and Tasmania. Records of the South Australian Museum, 32 (2), 143-154.

Opresko, D.M. (2001) A new species of antipatharian coral, Bathypathes bayeri, (Cnidaria: Anthozoa: Antipatharia) from the Galapagos Islands. Bulletin of the Biological Society of Washington, 10, 204-209.

Opresko, D.M. (2002) Revision of the Antipatharia (Cnidaria: Anthozoa), Part II, Schizopathidae. Zoologische Mededelingen, Leiden, 76, 411-442.

Opresko, D.M. (2005) New genera and species of antipatharian corals (Cnidaria: Anthozoa) from the North Pacific. Zoologische Mededelingen, Leiden, 79, 129-165.

Opresko, D.M. (2011) Nomenclatural note: Heteropathes (Cnidaria: Anthozoa: Antipatharia: Cladopathidae): a new name for Heliopathes Opresko, 2003. Zootaxa, 2782, 67-68.

Opresko, D.M. (2015) New species of black corals (Cnidaria: Anthozoa: Antipatharia) from New Zealand and adjacent regions. New Zealand Journal of Zoology, 42 (3), 145-164.

Opresko, D.M. \& Wagner, D. (2020) New species of black corals (Cnidaria:Anthozoa: Antipatharia) from deepsea seamounts and ridges in the North Pacific. Zootaxa, 4868 (4), 543-559. https://doi.org/10.11646/zootaxa.4868.4.5

Pasternak, F.A. (1958) Deep-sea antipatharians (Antipatharia) of the Kuril-Kamchatka Trench. Trudy Instituta Okeanologii, 27, 180-191. [in Russian]

Pasternak, F.A. (1977) Antipatharia. Galathea Report, 14, 157-164.

Pourtalès, L.F. de (1868) Contributions to the fauna of the Gulf Stream at great depths (2nd series) (with a note by L. Agassiz). Bulletin of the Museum of Comparative Zoology at Harvard College, 1 (7), 121-142.

Quattrini, A.M., Faircloth, B.C., Duenas, L.F., Bridge, T.C.L., Brugler, M.R., Calixto-Borja, I.F., DeLeo, D.M., Foret, S., Her- 
rera, S., Lee, S.M.Y., Miller, D.J., Prada, C., Radis-Baptista, G., Ramirez-Portilla, C., Sanchez, J.A., Rodriguez, E. \& McFadden, C.S. (2017) Universal target-enrichment baits for anthozoan (Cnidaria) phylogenomics: new approaches to long-standing problems. Molecular Ecology Resources, 18, 281-295. https://doi.org/10.1111/1755-0998.12736

Roule, L. (1902) Notice préliminaire sur les Antipathaires provenant des collections du Prince du Monaco. Mémoires de la Société zoologique de France, 15, 228-239.

Roule, L. (1905) Description des Antipathaires et Cérianthaires Recueillis par S.A.S. le Prince de Monaco dans l'Atlantique Nord. Résultats des Campagnes Scientifiques du Prince de Monaco, 30, 1-99. https://doi.org/10.5962/bhl.title.59328

Schultze, L.S. (1903) Die Antipatharien der Deutschen Tiefsee-Expedition, 1898-1899. Wissenschaftliche Ergebnisse der deutschen Tiefsee-Expedition auf dem Dampfer Valdivia, 3, 98-100.

Stone, R.P. \& Shotwell, S.K. (2007) State of deep coral ecosystems in the Alaska Region: Gulf of Alaska, Bering Sea and the Aleutian Islands. In: Lumsden, S.E., Hourigan, T.F., Bruckner, A.W. \& Dorr, G. (Eds.), The State of Deep Coral Ecosystems of the United States, NOAA Technical Memorandum CRCP-3. NOAA, Silver Spring, Maryland, pp. 65-108.

Thomson, J.A. (1905) "Scotia" Collections: Scottish Antarctic Expeditions. - Report on the Antipatharians. Proceedings of the Royal Physical Society of Edinburgh, 16, 76-79.

Totton, A.K. (1923) Coelenterata, Part III, Antipatharia (and their Cirripede commensals). British Antarctic (Terra Nova) Expedition, 1910-1913, Natural History Reports, Zoology, 5, 97-120.

van Pesch, A.J. (1914) The Antipatharia of the Siboga Expedition. Siboga-Expeditie Monographes, 17, 1-258. 